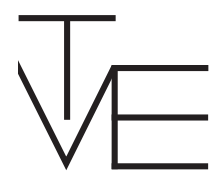

\title{
Ferðapjónusta og virkjanir til bjargar byggðum?
}

\author{
Anna Dóra Sæpórsdóttir og Porkell Stefánsson ${ }^{1}$
}

\begin{abstract}
Ágrip
Tækifæri á sviði ferðapjónustu og nýtingar orkuauðlinda eru oft nefnd sem leiðir til pess að takast á við breytta atvinnuhætti, sporna við fólksfækkun í dreifbýli og skapa verðmæti. Báðar greinarnar nýta náttúruna sem auðlind en geta pær farið saman eða eru fyrirsjáanlegir hagsmunaárekstrar milli peirra? Til pess að komast að pví hvort ferðapjónustuaðilar telji fyrirhugaðar virkjunarhugmyndir rýra möguleika ferðapjónustunnar til að efla byggð í landinu voru tekin hálfstöðluð viðtöl við 65 ferðapjónustuaðila á sex svæðum á landinu. Að mati viðmælenda er ferðapjónustan sú atvinnugrein sem býður upp á mesta möguleika til framtíðar til að efla atvinnulíf í dreifbýli og höfðu peir flestir séð pess glögg merki undanfarin ár. Margir viðmælenda töldu orkuvinnslu og ferðapjónustu fara illa saman vegna neikvæðra áhrifa orkuvinnslu á náttúruna, grundvallarauðlind ferðapjónustunnar. Óvissa um hvar verður virkjað í framtíðinni pótti jafnframt hafa tafið fyrir fjárfestingu og markaðssetningu í ferðapjónustu á ákveðnum svæðum. Nokkrir viðmælenda nefndu dæmi um farsæla sambúð orkuframleiðslu og ferðapjónustu og kom fram að góð samvinna milli greinanna gæti dregið úr hagsmunaárekstrum á milli peirra. Peir töldu að tekjur af báðum atvinnugreinunum mættu skila sér betur til svæðanna par sem pær verða til.
\end{abstract}

1 Anna Dóra Sæpórsdóttir er prófessor í ferðamálafræði og deildarforseti Líf- og umhverfisvísindadeildar Háskóla Íslands. Netfang: annadora@hi.is. Porkell Stefánsson er sérfræðingur við rannsóknir á ferðamennsku hjá Land- og ferðamálafræðistofu Háskóla Íslands. 


\begin{abstract}
Opportunities in the tourism industry along with the harnessing of energy resources are commonly referred to as means of dealing with changes in employment structure, to counteract depopulation in rural areas, and as a way to create capital. Both fields utilize nature as a resource, but can they coexist or are conflicts foreseeable? In order to find out whether the tourist industry consider that proposed power plant developments will diminish the possibilities of the tourism sector to strengthen local settlements semi-structured interviews were conducted with 65 tourist service providers in six different parts of Iceland. In the opinion of the interviewees the tourism sector is the industry that offers the best long-term possibilities to strengthen the economy in rural areas and most of them had seen clear indications of this in recent years. Many interviewees felt that energy production and tourism do not concur because the negative effects energy production can have on nature, the core resource for the tourist industry. Uncertainty over where power developments will be located was thought to have delayed investment and marketing efforts in certain areas. A few of the interviewees mentioned examples of successful cohabitation of energy production and tourism and it was pointed out that favourable collaboration between the two industries could diminish their conflict of interest. Moreover, it was stated that the income from both industries could reach the areas where it was generated more effectively.
\end{abstract}

JEL flokkun: Z32; L83; R58; Q26; O18; O13

Lykilorð: Ferðapjónusta; ferðamennska; rammaáætlun; náttúruvernd og orkunýting; byggðapróun; virkjanir.

Keywords: Tourist industry; tourism; master plan; nature conservation; energy production; regional development; power plants.

\title{
Tourism and power plants as aids in regional development.
}

\section{Inngangur}

Ferðapjónusta og nýting orkuauðlinda eru gjarnan nefnd í sömu andrá pegar talað er um hvar tækifæri Íslands til verðmætasköpunar liggja. Auðlindir beggja greina dreifast víða um land og hafa á undaförnum áratugum nýst til að efla byggðir landsins. Virkjunum og stóriðju var lengi hampað af stjórnvöldum sem einni mikilvægustu leið til að efla byggð í landinu og oft á tíðum einu leiðinni. Hjáróma bentu náttúruverndarsinnar á að náttúruna bæri að vernda, bæði hennar sjálfrar vegna en einnig vegna fegurðar óbeislaðra nátt- 
úrukraftanna. Pau rök máttu sín oft lítils i umræðunni hjá pjóð sem var að brjótast úr sárri fátækt og byrja að byggja upp velferð sína (sjá t.d. Unnur Birna Karlsdóttir, 2010). Til pess að leysa úr peim ágreiningi sem var um pessi mál í pjóðfélaginu fóru stjórnvöld af stað með verkefni sem í daglegu tali kallast rammaáætlun og gengur út á pað að flokka vatnsföll og háhitasvæði í verndarflokk eða orkunýtingarflokk. Fyrsti áfangi rammaáætlunar var unninn á árunum 1999-2003 og annar áfangi 2004-2010. Vinna við priðja áfanga hófst árið 2013 og er áætlað að ljúka honum árið 2017 (Stefán Gíslason, 2016). Samkvæmt rammaáætlun meta fjórir faghópar, skipaðir sérfræðingum á ýmsum sviðum, áhrif virkjana og metur einn peirra, p.e. faghópur 2, áhrif virkjana á ferðamennsku og útivist.

Frá pví að vinnan við rammaáætlun hófst hefur umfang ferðapjónustu í hagkerfinu margfaldast og er greinin nú stærsta gjaldeyrisskapandi atvinnugrein landsins (Hagstofa Íslands, 2017d). Í ljósi pess að náttúran er aðalástæða pess að ferðamenn koma hingað til lands (Ferðamálastofa, 2015) fá fegurðarrökin nú meiri punga í umræounni en áđur - en nú á peim forsendum að á fegurðinni megi græða.

Á svæðum á Íslandi par sem störfum í sjávarútvegi og landbúnaði hefur fækkað hefur verið litið á ferðapjónustuna sem tæki til að efla atvinnulíf og skapa tekjur (Byggðastofnun, 1999, 2015; Gunnar Pór Jóhannesson og Edward H. Huijbens, 2010; Karl Benediktsson og Unnur Dís Skaptadóttir, 2002; Pingskjal nr. 934/1989-1990). Slíkt er einnig vel pekkt á jaðarsvæðum annars staðar í heiminum par sem frumframleiðsla hefur dregist saman og velmenntað yngra fólk flytur burt (Briedenhann og Wickens, 2004; Contini, Scarpellini og Polidori, 2009; Sharpley og Vass, 2006). Birtingarmynd pessa má t.d. sjá í orðræðunni að stofnun Vatnajökulspjóðgarðs par sem efnahagslegur ávinningur nærliggjandi byggða af ferðapjónustu var fyrirferðarmikill (Karl Benediktsson og Guðríður Porvarðardóttir, 2005).

Um helmingur virkjunarhugmynda í priðja áfanga er á hálendinu en að mati ferðamanna er lítt snortin náttúra eitt aðalaðdráttarafl hálendisins (Anna Dóra Sæbórsdóttir, 2010, 2014). Aðrar virkjunarhugmyndir eru ýmist í nágrenni við vinsæla ferðamannastaði eða á svæðum sem tiltölulega fáir ferðamenn heimsækja - enn sem komið er. Pær ákvarðanir sem teknar eru um landnýtingu, hvort sem er til orkuvinnslu eða náttúruskoðunar, munu pví hafa áhrif á landsbyggðina sem og ferðapjónustuna víða um land. Kannanir (sjá t.d. Bylgja Árnadóttir, Guðbjörg Andrea Jónsdóttir, og Hafsteinn Einarsson, 2016a, 2016b; Guðbjörg Andrea Jónsdóttir og Hafsteinn Einarsson, 2016; Hafsteinn Einarsson, 2016) sýna að skiptar skoðanir eru meðal landsmanna á frekari nýtingu orkulinda landsins og til hvaða sjónarmiða beri að líta. Í pessari grein verður rýnt nánar í pessi mál par sem einum peirra hópa sem eiga mikið undir í pessari umræðu er gefin rödd, en pað eru ferðapjónustuaðilar sem nýta svæði í nágrenni við fyrirhugaðar virkjunarframkvæmdir. 
Í greininni eru kynntar niðurstöður viðtalsrannsóknar sem gerð var meðal ferðapjónustuaðila par sem leitast er við að svara pví hvort peir telji fyrirhugaðar virkjunarhugmyndir geta rýrt möguleika ferðapjónustunnar til að efla byggð í landinu. Ummæli viðmælenda eru skoðuð með hliðsjón af líkani peirra Ritchies og Crouch (2003) um samkeppnishæfni áfangastaða en petta líkan hjálpar til við að skilja áhrif virkjana á samkeppnisumhverfi ferðapjónustunnar.

\section{Búseta og atvinnulíf}

Miklar breytingar hafa orðið á búsetu Íslendinga síðustu áratugi en árið 1916 bjuggu um 20\% landsmanna á höfuðborgarsvæðinu, árið 1966 rúmlega helmingur landsmanna og nú um 64\% (mynd 1) (Hagstofa Íslands, 2016c). Pessi breyting búsetu hefur orðið í kjölfar breyttra atvinnuhátta til sjávar og sveita og hefur hún einkennst af fólksflutningum frá landbúnaðarhéruðum og sjávarplássum til höfuðborgarsvæðisins. Pótt framleiðsluvirði bæði landbúnaðar- og sjávarafurða hafi verið að aukast undanfarin ár (Hagstofa Íslands, 2016a, 2016b) hefur tæknipróun og sampjöppun leitt til pess að störfum í greinunum hefur fækkað (Karl Benediktsson og Anna Karlsdóttir, 2011).

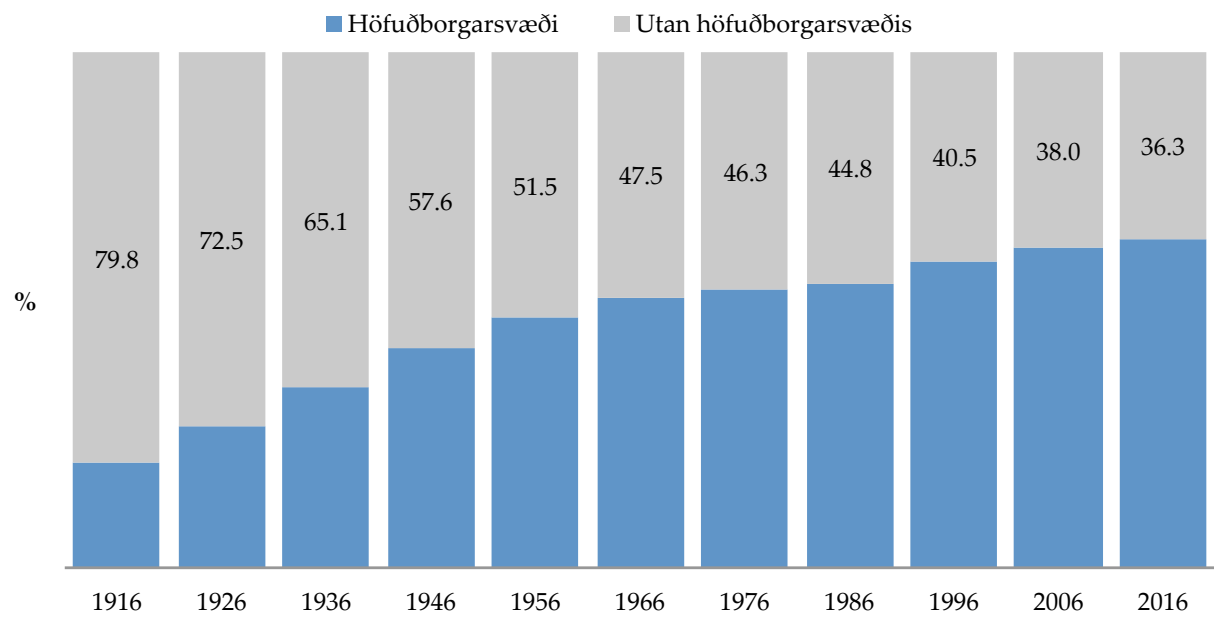

Mynd 1. Hlutfall (\%) landsmanna með búsetu á höfuðborgarsvæðinu og utan pess.

Unnið úr gögnum Hagstofu Íslands (2016c).

Árið 1965 töldust rúm 15\% allra ársverka á landinu til fiskveiða og fiskvinnslu en árið 2015 störfuðu rúm 4\% Íslendinga í greininni (Hagstofa Íslands, 2016d). Sjávarútvegur heldur pó stöðu sinni sem ein helsta útflutningsgrein pjóðarinnar, pví að heildarverðmæti aflans er nú mun meira en á árunum fyrir og eftir aldamót pótt heildarfiskaflinn hafi pá verið tvöfalt 
meiri (Hagstofa Íslands, 2016b). Aflasamdrátturinn hefur, ásamt breytingum í fiskvinnslu, sampjöppun í greininni og útflutningi á ferskum fiski, valdið pví að færri störf eru nú í greininni en áður og fólki hefur fækkað í sjávarplássum víða um land (Karl Benediktsson og Anna Karlsdóttir, 2011; Póroddur Bjarnason, 2012).

Landbúnaður var áður ein stærsta atvinnugrein landsins. Um 32\% vinnuaflsins störfuðu við landbúnað árið 1940 (Bændasamtök Íslands, 2010) en aldarfjórðungi síðar, árið 1965, voru störf í landbúnaði, kjöt- og mjólkurvinnslu um $14 \%$ allra starfa. Störfum í greininni hefur haldið áfram að fækka og árið 2015 störfuðu einungis um 2\% Íslendinga við landbúnað (Hagstofa Íslands, 2016d). Líkt og í sjávarútvegi gætir sampjöppunar í landbúnaði par sem bú eru nú færri og stærri en áður, p.e.a.s. skráðum gripaeigendum fer fækkandi og fleiri gripir eru á hvern eiganda (Bændasamtök Íslands, 2010). Algengt er að bændur á minni búum hafi fært sig úr einsleitri framleiðslu yfir í fjölbreytta gæðaframleiðslu, t.d. með heimavinnslu afurða eða beinni sölu til neytenda, auk pess sem bændur eru í auknum mæli farnir að drýgja tekjur sínar með ýmiss konar ferðapjónustu (Magnfríður Júlíusdóttir, Anna Karlsdóttir, Karl Benediktsson, Inga Elísabet Vésteinsdóttir og Sigfús Steingrímsson, 2009).

Erlendum ferðamönnum sem koma til landsins hefur fjölgað mjög síðustu ár, að meðaltali $24 \%$ á ári undanfarin sex ár, og komu um 1,8 milljónir erlendra ferðamanna til landsins árið 2016 (Ferðamálastofa, 2017). Jafnframt hafa tekjur af erlendum ferðamönnum aukist og er ferðapjónusta nú stærsta gjaldeyrisskapandi atvinnugreinin, með um 31\% af heildarútflutningstekjum Islands (Hagstofa Íslands, 2017d). Flestir, eða um 80\% erlendra ferðamanna sem koma til landsins á sumrin, koma vegna náttúrunnar og $77 \%$ á veturna (Ferðamálastofa, 2015). Ferðapjónustan var lengi vel mjög árstíðabundin grein par sem um helmingur ferðamanna kom til landsins yfir sumarmánuðina. Undanfarin ár hefur pó orðið mikil breyting par á, par eð árið 2016 var hlutfall peirra sem komu til landsins um sumarið komið niður í 38\% og komur á öðrum tímum ársins par með komnar í 62\% (Ferðamálastofa, 2017). Á sumrin (maí-ágúst) ferðast ferðamenn víðs vegar um landið og eru um $65 \%$ af gistinóttum erlendra ferðamanna á landsbyggðinni en um 35\% á höfuðborgarsvæðinu (Hagstofa Íslands, 2017b). Í öðrum mánuðum ársins snýst petta hins vegar við par sem $62 \%$ gistinátta eru á höfuðborgarsvæðinu en pá fara erlendir ferðamenn gjarnan í dagsferðir til nærliggjandi náttúruskoðunarstaða. Hlutfall gistinátta erlendra ferðamanna yfir hásumarið hefur lækkað síðasta áratuginn (mynd 2): Utan höfuðborgarsvæðisins voru um 87\% allra gistinátta ársins 2007 í maí til ágúst en pað hlutfall hafði lækkað niður í 65\% árið 2016. Á sama tíma minnkaði árstíðarsveifla á höfuðborgarsvæðinu einnig mikið en hlutfall gistinátta í maí til ágúst fór úr 52\% árið 2007 í 39\% árið 2016. 


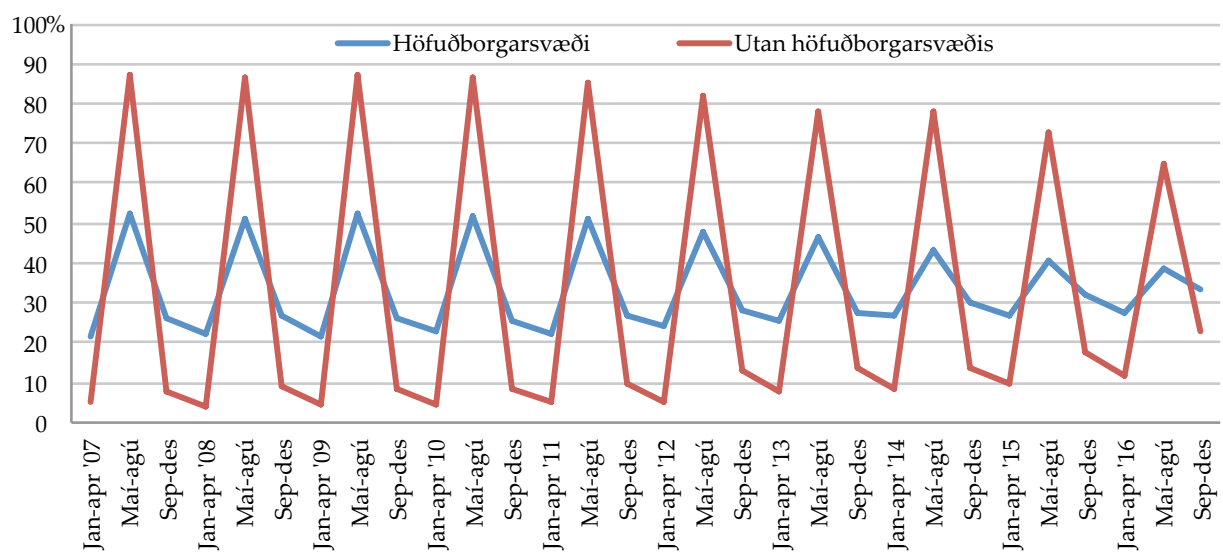

Mynd 2. Próun árstíðarsveiflu gistinátta á höfuðborgarsvæðinu og utan pess árin 2007-2016.

Unnið úr gögnum Hagstofu Íslands (2017b).

Störfum í ferðapjónustu hefur fjölgað mikið undanfarin ár og var ársmeðaltal launpega í greininni um 24.100 manns árið 2016 sem eru rúm 13\% launpega á Íslandi (Hagstofa Íslands, 2017a). Um 70\% pessara starfa eru á höfuðborgarsvæðinu og 30\% á landsbyggðinni (Hagstofa Íslands, 2016d). Sumarið 2016 störfuðu um 27 púsund manns í greininni en á fyrstu mánuðum ársins um 20 púsund. Раð pýðir að greinin er farin að skipta miklu máli í atvinnulífi í landinu prátt fyrir að enn gæti árstíðasveiflu hvað varðar fjölda starfa í henni og ferðapjónustan er að próast frá pví að vera talsvert árstíðabundin í að geta boðið fjölda heilsárstarfa og aukið byggðafestu víða um land.

Íslendingar eru jákvæðir gagnvart komu erlendra ferðamanna til landsins og ferðapjónustunnar almennt. Telja peir að koma erlendra ferðamanna til landsins stuðli að sterkara hagkerfi, bættum lífsgæðum, auknu framboði verslunar og pjónustu og til fjölbreyttara mannlífs. Um priðjungi finnst pó fjöldi ferðamanna of mikill á sumrin. Jafnframt telur tæplega helmingur að ferðamenn spilli náttúru landsins og tæplega fjórðungur að peir spilli upplifuninni af náttúru landsins. Um $74 \%$ telur auk pess skorta á framtíðarsýn fyrir greinina að hálfu hins opinbera (Félagsvísindastofnun, 2014).

Hvergi í Evrópu er framleitt meira rafmagn á hvern íbúa úr endurnýjanlegum orkugjöfum en á Íslandi en hér er framleitt 2,13 sinnum meira en í Noregi, sem er í öðru sæti, miðað við sama mælikvarða. Sé ekki tekið tillit til íbúafjölda er Ísland í 14. sæti meðal Evrópulanda í framleiðslu á endurnýjanlegri orku (U.S. Energy Information Administration, 2016). Orkuframleiðsla á Íslandi hefur aukist mikið undanfarinn áratug, fyrst og fremst vegna uppbyggingar stóriðju sem notar um $76 \%$ af peirri orku sem framleidd er í landinu (Orkustofnun, 2016). Par eru prjú fyrirtæki stærst og nota um 70\% 
af framleiddri orku, en pað eru álverin prjú; á Reyðarfirði (4.954 GWh á ári), á Grundartanga (4.455 GWh) og í Straumsvík (3.587 GWh) (Orkustofnun, 2015). Útflutningur áls skapar nú 20\% af útflutningstekjum landsins (Hagstofa Íslands, 2017d). Önnur stóriðjufyrirtækni nota mun minna af orku en pað eru járnblendiverksmiðjan á Grundartanga (1.060 GWh), aflpynnuverksmiðjan á Akureyri (578 GWh), kísilver í Helguvík (208 GWh) og gagnaver í Reykjanesbæ (78 GWh) en samtals eru petta 7 fyrirtæki (Orkustofnun, 2015). Líklegt er að fleiri stóriðjufyrirtæki bætist við á næstu árum og eru t.d. framkvæmdir við kísilverksmiðju á Bakka við Húsavík langt komnar.

Árið 2016 störfuðu að meðaltali 2.018 við framleiðslu málma í hverjum mánuði en sé tekið mið af starfamargfaldara stóriðju (2,43skv. Hagfræðistofnun, 2005) eru afleidd störf 2.886 til viðbótar og pví hafa pví 2,7\% starfandi fólks atvinnu af stóriðju (mynd 3). Um 57\% peirra starfa eru á landsbyggðinni og 43\% á höfuðborgarsvæðinu (Hagstofa Íslands, 2016d).

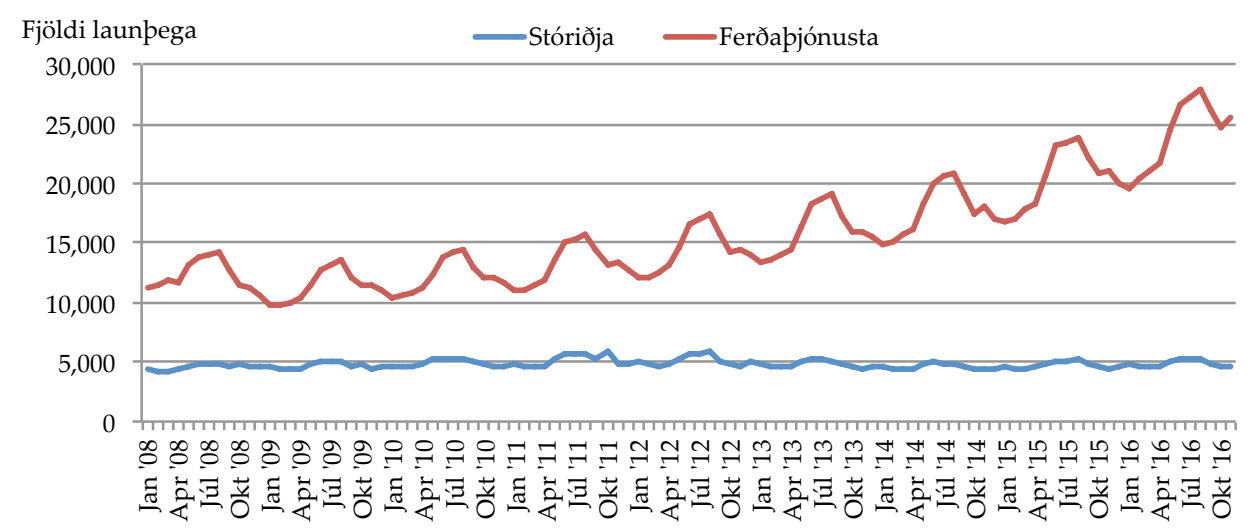

Mynd 3. Fjöldi launpega í ferðapjónustu og stóriðju 2008-2016.

Unnið úr gögnum Hagstofu Íslands (2017a).

Beinar tekjur sveitarfélaga landsins vegna fasteignagjalda af virkjunum eru alls um 480 milljónir króna á ári, sem, að mati Hagfræðistofnunar (2015), er lítið miðað við umfang mannvirkjanna. Tekjurnar koma til vegna stöðvarhúsa en ekki vegna uppistöðulóna, stíflna eða raflína. Pað getur pví farið svo að tekjur vegna virkjunar fari til eins sveitarfélags en að annað sveitarfélag sitji uppi með allan fórnarkostnaðinn sem felst í rýrari gæðum umhverfisins, t.d. til útivistar og ferðamennsku. Sveitarfélög par sem raforkan er nýtt fá tekjur í formi fasteignaskatts frá iðnfyrirtækjum og starfsmenn fyrirtækjanna greiða útsvar til peirra sveitarfélaga par sem peir hafa lögheimili. Skattar afleiddra greina skila sér einnig til peirra sveitarfélaga par sem pau eru starfrækt. 
Kárahnjúkavirkjun og álverið á Reyðarfirði eru dæmi um pessa misskiptingu tekna og áhrifa virkjana á Austurlandi. Íbúum á Fljótsdalshéraði fjölgaði um 937 og um tæplega 700 í Fjarðabyggð en peim fækkaði um 10 í Fljótdalshreppi árin 2003-2016 (Hagstofa Íslands, 2017c) (mynd 4). Tekjur sveitarfélaganna jukust mismikið og af misjöfnunum ástæðum: Stöðvarhúsið er í Fljótsdalshreppi, sem fær um 80 milljónir króna á ári í fasteignagjöld af virkjuninni. Megnið af röskun umhverfisins, eins og t.d. Hálslón og stíflumannvirki sem reist voru meðal annars við Hafrahvammagljúfur, eru hins vegar á Fljótsdalshéraði en af peim eru engin fasteignagjöld greidd og fékk sveitarfélagið pví engar beinar tekjur af virkjuninni (Hjalti Jóhannesson o.fl., 2010). Á pessu urðu pó breytingar árið 2016 pegar Hæstiréttur úrskurðaði аð virkjunaraðilum beri að greiða fasteignagjöld af vatnsréttinum (Hrd. 22/2015), og greiðir nú Landsvirkjun Fljótsdalshéraði og Fljótdalshreppi fasteignagjöld af vatnsréttindum Kárahnjúkavirkjunar.

Ekki eru greidd gjöld fyrir háspennulínuna sem tengir virkjunina við álverið og liggur um sveitarfélögin prjú, sem nefnd eru hér að ofan. Fjarðaál er staðsett í Fjarðabyggð, sem fær greidda fasteignaskatta vegna álversins, auk útsvarstekna starfsmanna sem hafa lögheimili í sveitarfélaginu. Samkvæmt skýrslu Hjalta Jóhannessonar o.fl. (2010) starfa um 480 manns við álverið og um 300 til viðbótar í tengdum störfum. Um 54\% starfsmanna eru af Austurlandi, par að um 70\% úr Fjarðabyggð en flestir aðrir frá Egilsstöðum. Hinn tæpi helmingurinn er annars staðar að af landinu. Á framkvæmdatíma ál-

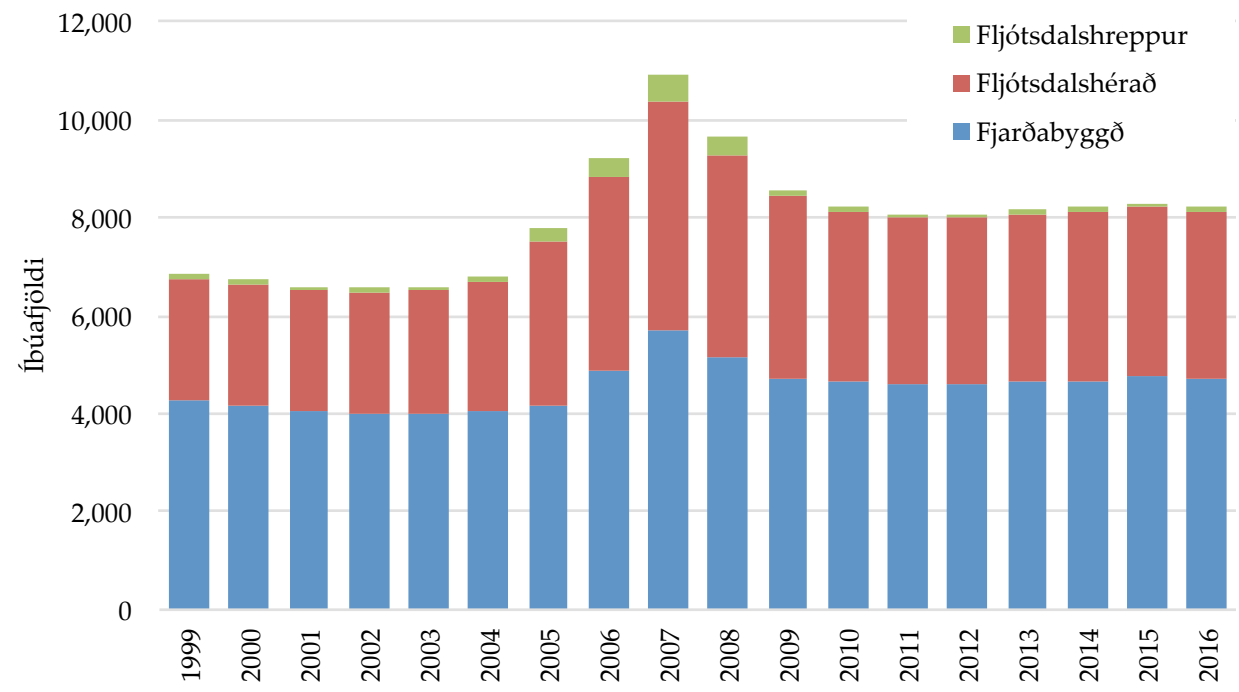

Mynd 4. Íbúafjöldi í sveitarfélögunum premur sem urðu fyrir mestum áhrifum af Kárahnjúkavirkjun og Fjarðaáli. 
versins og virkjunarinnar, p.e. á árunum 2002-2006, jókst útsvar hlutfallslega mest á landinu í pessum premur sveitarfélögum. Fjarðabyggð og Fljótsdalshérað fjárfestu í ýmiss konar grunngerð vegna fyrirhugaðrar fólksfjölgunar en pegar upp var staðið hafði verið farið of geyst í pær og sátu sveitarfélögin uppi til skemmri tíma með töluvert af auðu húsnæði og vannýtta innviði í götum og lögnum. Aðrir innviðir voru styrktir með nýjum vegum, brúm, veggöngum og útflutningshöfn.

Ásgeir Jónsson og Sigurður Jóhannesson (2011) hafa bent á að orkusala til stóriðju hafi skilað litlum arði til pjóðarbúsins, sérstaklega á síðari árum, en arðsemi af orkusölu til stóriðju hefur verið svipuð fjármagnskostnaði íslenska ríkisins vegna ábyrgðarinnar sem pað tókst á hendur við byggingu orkuveranna sem nauðsynleg voru til orkusölunnar. Starfsemi Landsvirkjunar hafi pví ekki skilað beinni auðlindarentu til pjóðarinnar heldur hafi hún dreifst til stórnotenda með lægra orkuverði en peir hefðu greitt ef starfsemin ætti að skila arði til pjóðarinnar.

Í sóknaráætlunum allra landshluta er fjallað um að nýta tækifæri í ferðapjónustu til að efla atvinnu á svæðunum. Á landsbyggðinni er stefnt að pví að fá ferðamenn til að dvelja lengur en nú á svæðunum og jafna árstíðasveiflu í greininni (sjá t.d. Eyping, 2015). Jafnframt kemur fram í sóknaráætlunum landshlutanna að stefna skuli að pví að nýta orku svæðanna í iðnað í heimabyggð (Byggðastofnun, 2015). Samkvæmt könnun Viðskiptaráđs Íslands (2011) telja stjórnendur í íslensku atvinnulífi mikil tækifæri enn leynast í nýtingu orkuauðlinda landsins, sérstaklega í smáum og arðbærum einingum sem stuðla að aukinni samkeppni á raforkumarkaðnum og fjölbreytni í íslenskum iðnaði. Almenningur á Íslandi virðist vera á sama máli en meirihluti (75\%) peirra 1.104 einstaklinga sem svaraði netkönnun Félagsvísindastofnunar (Hafsteinn Einarsson, 2016) var hlynntur virkjunum ef efla ætti aðra starfsemi en stóriðju og enn fleiri, eða 81\%, ef rafvæða ætti bílaflota og almenningssamgöngur. Hins vegar voru aðeins $15 \%$ hlynnt virkjunum til að auka stóriðju á Íslandi. Sá páttur sem svarendur töldu að ætti að vega pyngst í ákvörðunum um að reisa fleiri virkjanir á Íslandi var náttúruvernd, en 34\% taldi svo vera. Næstmikilvægustu pættirnir voru heilsa fólks (15\%) og atvinnuuppbygging á landinu (14\%). Í 3. áfanga rammaáætlunar voru viðhorf heimamanna til virkjana könnuð í Skagafirði, Skaftárhreppi og í nágrenni Pjórsár. Könnunin leiddi í ljós að í Skagafirði telja 70\% (pó aðeins 54\% kvenna) að fyrirhugaðar vatnsaflsvirkjanir hefðu jákvæð áhrif á sveitarfélagið (Bylgja Árnadóttir o.fl., 2016b), 60\% í Skaftárhreppi (Bylgja Árnadóttir o.fl., 2016a) og 54\% á Pjórsársvæðinu (Guðbjörg Andrea Jónsdóttir og Hafsteinn Einarsson, 2016). Forsenda fyrir jákvæðu viðhorfi margra var pó að orkan yrði nýtt í atvinnuuppbyggingu innan svæðisins en pó helst ekki til stóriðju. Niðurstöður pessara rannsókna benda pví til pess að munur sé á pví hvað pykir vega pyngst í ákvörðunum um virkjanir eftir pví hvort um heimamenn 
á virkjunarsvæðum eða landsmenn almennt er að ræða: Landsmenn í heild töldu, eins og áður segir, náttúruvernd vega pyngst en heimamenn á svæðunum lögðu hins vegar mesta áherslu á að orka úr virkjununum yrði nýtt í atvinnuuppbyggingu á svæðinu. Rannsókn Bergmanns, Colombos og Hanleys (2008) vegna virkjana í sveitum Skotlands sýndi svipaða skiptingu, en par voru peir sem bjuggu í péttbýli hlynntastir peim virkjunarhugmyndum sem höfðu minnst neikvæð áhrif á umhverfið (landslag, lífríki og mengun) en peir sem bjuggu í sveitum voru aftur á móti hlynntastir virkjunum sem sköpuðu varanleg störf í héraði. Niðurstöður peirra benda til pess að hagsmunaárekstrar milli borgarbúa og landsbyggðarfólks út af fyrirhuguðum endurnýjanlegum virkjunarkostum séu líklegir (Bergmann o.fl., 2008).

\section{Samkeppnishæfni áfangastaða}

Ritchie og Crouch (2003) settu fram líkan um samkeppnishæfni áfangastaða par sem leitast er við að varpa ljósi á hæfni áfangastaðar til að standast samkeppni við aðra staði, sem er lykilatriði í pví hvernig staðnum farnast í alpjóðlegri samkeppni. Samkeppnishæfni áfangastaða skilgreindu peir sem „hæfileikann til að auka eyðslu ferðamanna, laða að fleiri ferðamenn og á sama tíma bjóða peim upp á fullnægjandi og eftirminnilega upplifun á pann hátt að pað sé arðbært, stuðli að aukinni velferð heimamanna og varðveiti náttúruauðlindir áfangastaðarins fyrir komandi kynslóðir" (Ritchie og Crouch, 2003, bls. 2). Líkan peirra byggist í grunninn á fimm krafta líkani Porters (1980) og pjóðardemantslíkani Porters (1990) en í stað pess að horfa á samkeppnishæfni fyrirtækja eða pjóðar pá horfa peir á áfangastaði ferðamanna, hvort sem um er að ræða ríki eða minni svæði innan einstakra ríkja.

Hugtökin hlutfallslegir yfirburðir (e. comparative advantage) og samkeppnisyfirburðir (e. competitive advantage) skapa mikilvægan grunn að skilningi á samkeppnishæfni áfangastaða. Hlutfallslegir yfirburðir samanstanda af auðlindunum á staðnum, bæði náttúrulegum og sköpuðum. Hlutfallslegir yfirburðir ná pannig yfir pær auðlindir sem eru á viðkomandi áfangastað en samkeppnisyfirburðir ná hins vegar yfir getu áfangastaðarins til að nýta sér pessar auðlindir. Pannig er áfangastaður sem er ríkur af auðlindum ekki endilega samkeppnishæfari en áfangastaður með takmarkaðar auðlindir ef sá staður notar pað litla sem hann hefur á skilvirkari hátt. Saman skapa hlutfallslegir yfirburðir og samkeppnisyfirburðir samkeppnishæfni áfangastaða.

Líkan peirra Ritchies og Crouch (2003) er kerfislíkan (e. systemic model) eins og pjóðardemantslíkan Porters (1990), p.e. pað er samansett úr ótal páttum og viðföngum og getur breyting á einum peirra haft áhrif á öll önnur. Á petta hafa áhrif annars vegar aðstæður í nærumhverfinu (e. competitive (micro) environment), pað er staðurinn sjálfur, önnur svæði sem eru í samkeppni við hann, ferðapjónustan á svæðinu, markaðir, almenningur og hagsmunaaðilar. Hins vegar eru pað áhrifin af alpjóðlegu umhverfi (e. glo- 
bal (macro) environment) eins og t.d. alpjóðavæðing, tæknivæðing, vaxandi áhugi á náttúruvernd og aukið lýðræði í heiminum. Líkan Ritchies og Crouch (2003) dregur fram 35 viðföng sem eru flokkuð í fimm meginpætti (mynd 5) og hafa áhrif á hversu samkeppnishæfir áfangastaðir eru:

1. Grundvallarauðlindir og aðdráttarpættir (e. core resources and attractors) eru peir pættir sem gera áfangastaðinn heillandi fyrir ferðamenn. Undir pað falla náttúru- og veðurfar, saga og menning, afpreying, sérviðburðir, grunngerð ferðapjónustu og markaðstengsl.

2. Stuðningspættir og auðlindir (e. supporting factors and resources) eru grunnurinn sem árangursrík ferðapjónusta byggist á: innviðir, aðgengileiki, grunnstoðir samfélagsins, gestrisni, fyrirtækjaumhverfi og pólitískur vilji. Velgengni ferðapjónustunnar er samtvinnuð stöðu annarra greina eins og samgangna, fjarskipta, tækni, orkuframleiðslu og landbúnaðar. Gengi greinarinnar er jafnframt háð stjórnmálum og frammistöðu á sviði umhverfismála.

3. Stefnumótun, áætlanagerð og próun áfangastaðar (e. destination policy, planning and development). Stefnumótun, gildi og skoðanir, framsýni, staðfærsla/auðkenning, próun, markaðs-/samstarfsgreining, mat og eftirlit og endurskoðun.

4. Stýring áfangastaðar (e. destination management) hefur áhrif á viðhorf ferðamanna til helstu auðlinda og aðdráttarpunkta áfangastaðarins og stuðlar að sjálfbærni ferðapjónustunnar. Undir stýringu fellur skipulag, markaðssetning, gæði pjónustu/upplifunar, pekking og rannsóknir, efling mannauðs, fjármögnun, gestastýring, umsjá auðlinda og krísustjórnun.

5. Áhrifapættir á val áfangastaðar (e. qualifying and amplifying determinants) eru úrslitapættir sem geta verið eins konar pak á samkeppnishæfni áfangastaðar en fara að litlu leyti eftir pví sem á sér stað innan hinna flokkanna. Petta eru staðsetning, öryggi, verðlag, nálægir og gagnháðir staðir, ímynd og polmörk. 


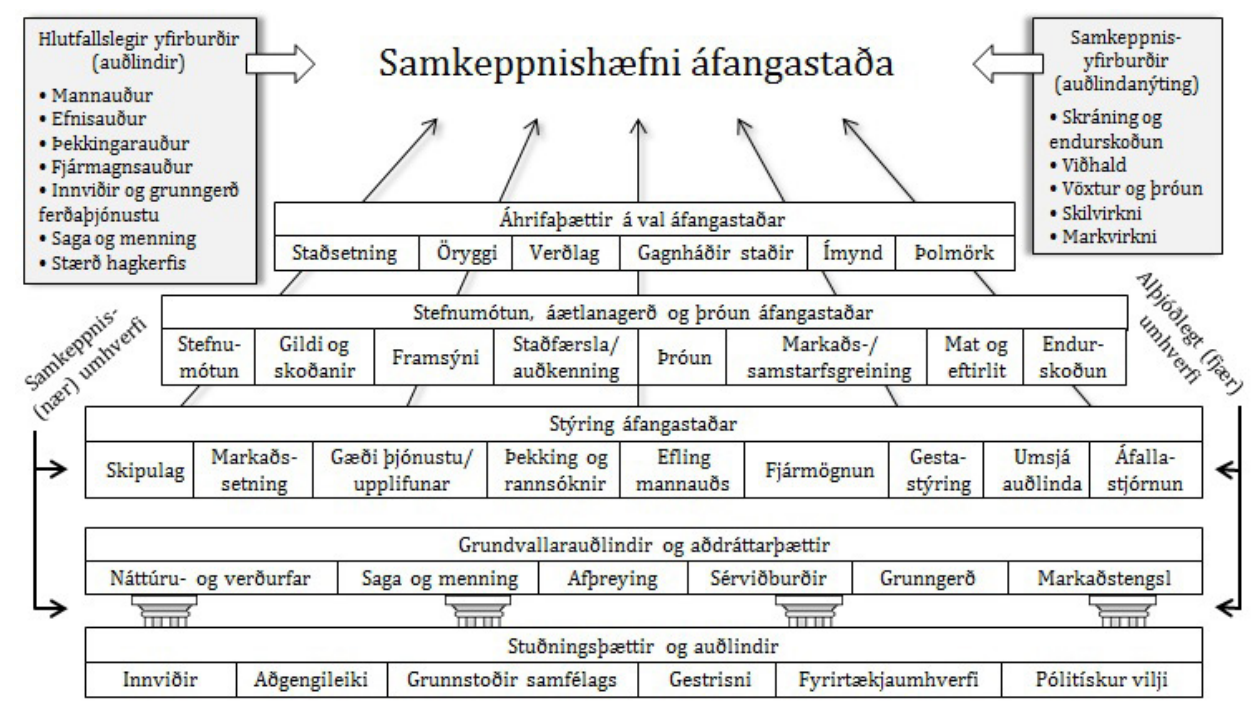

Mynd 5. Líkan um samkeppnishæfni áfangastaða.

Heimild: Ritchie og Crouch (2003) (pýð. höf.).

Í pessari grein er ekki gerð tilraun til að fjalla um alla pá fjölmörgu pætti sem hafa áhrif á samkeppnishæfni áfangastaða heldur eingöngu pau atriði sem ferðapjónustuaðilar telja að myndu hafa áhrif á rekstrarumhverfi peirra ef reistar yrðu virkjanir á slóðum sem peir nýta. Rétt er að undirstrika að um er að ræða mat, trú, hugmyndir og ímynd ferðapjónustuaðila á pví hvað myndi gerast ef virkjun yrði byggð. Greinin byggir pannig orðræðugreiningu á hugmyndum ferðapjónustuaðila um áhrif virkjana, ef til virkjunar kæmi, á áhuga ferðamanna (viðskiptavina peirra) á að skoða náttúruna (söluafurðina) sem peir byggja viðskipti sín á. Umfjöllunin byggist á peirri hugmynd að náttúran sé félagsleg smíð (e. social construction) (sjá t.d. Castree, 2005; Castree og Braun, 2001) en með peirri hugmynd er gert ráð fyrir að skynjun og skilningur manna á náttúrunni eigi sér stað í ákveðnu menningarlegu samhengi og séu pví ávallt hlaðin menningarbundinni merkingu. Pað stýrir síðan pví hvernig menn líta á náttúruna, skilja hana og skynja. Ummæli viðmælenda eru pví ekki hlutlægur raunveruleiki (e. reality), p.e.a.s. pað sem myndi raunverulega breytast hjá ferðapjónustunni ef virkjað yrði.

\section{Viðtöl við ferðapjónustuaðila}

Gögnin sem pessi grein byggist á eru hálfstöðluð viðtöl sem tekin voru við ferðapjónustuaðila í byrjun árs 2016 vegna vinnu við 3. áfanga rammaáætlunar. Í 3. áfanga lagði Orkustofnun fram 84 virkjunarkosti og óskaði faghópur 2 sérstaklega eftir að rannsökuð yrðu áhrif prettán virkjana á ferðapjónustuna. Fjórar peirra eru í Skjálfandafljóti, prjár í Skagafirði, tvær á Sprengisandi, tvær á Reykjanesi, ein í Skaftá og ein við Hagavatn (mynd 6). 
Við val á viðmælendum var stuðst við markvisst úrtak (e. purposive sample) (sjá t.d. Berg, 2006) og leitast við að tala við ferðapjónustuaðila sem hafa beinna hagsmuna að gæta á pví svæði sem virkjanirnar gætu haft áhrif par eð peir eru með ferðir um svæðið eða reka gistingu í næsta nágrenni við umrætt virkjunarsvæði. Viðmælendum má skipta í prjá hópa:

1. Ferðapjónustuaðilar sem búa í nágrenni fyrrgreindra virkjana.

2. Fulltrúar ferðapjónustufyrirtækja sem eru staðsett annars staðar en koma með ferðamenn á svæði sem fyrrgreindar virkjanir myndu hafa áhrif á.

3. Aðilar sem koma að ferðapjónustu með öðrum hætti á fyrirhuguðum virkjunarsvæðum, svo sem forstöðumenn upplýsingamiðstöðva og starfsfólk pjóðgarða.

Rætt var við 63 aðila á sex svæðum: nítján í Skagafirði, sautján á höfuðborgarsvæðinu, átta í Skaftárhreppi, sex í Bláskógabyggð, sjö í Suður-Pingeyjarsýslu (Norðurpingi, Pingeyjarsveit og Skútustaðahreppi) og sex á Akureyri (mynd 6). Viðmælendur ráku fjölbreytta ferðapjónustu, par af ráku 12 gistingu, 14 voru með gistingu og ýmiss konar afpreyingarferðir, 13 með rútu- eða jeppaferðir, 7 með gönguferðir, 5 með göngu- og bílferðir, 4 með hestafyrirtæki, 6

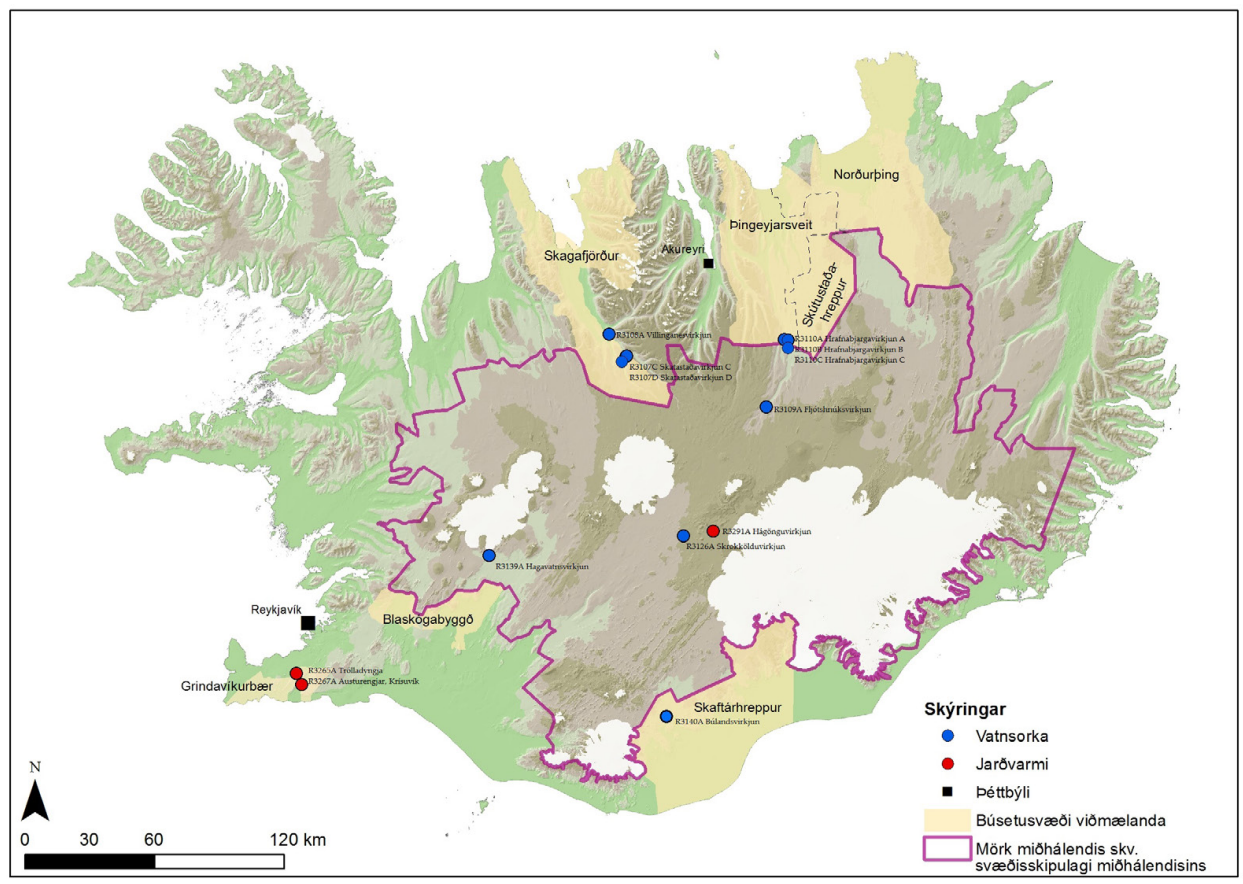

Mynd 6. Virkjunarhugmyndir sem ræddar voru og búseta viðmælenda. 
með söfn og upplýsingamiðstöðvar og 4 með annars konar rekstur (verslun, bátsferðir og hjólaferðir).

Byggðapróun pessara svæða hefur verið nokkuð mismunandi. Íbúum á höfuðborgarsvæðinu og Akureyri hefur fjölgað jafnt og pétt undanfarna tvo áratugi, íbúum í Bláskógabyggð fjölgaði til ársins 2007 en pá fækkaði peim í nokkur ár en hefur aftur fjölgað undanfarin fimm ár. Íbúum í Skagafirði og Suður-Pingeyjarsýslu hefur fækkað og í Skaftárhreppi varð fólksfækkun til ársins 2010 en par hefur fjölgað undanfarin fjögur ár (mynd 7) (Hagstofa Íslands, 2017c).

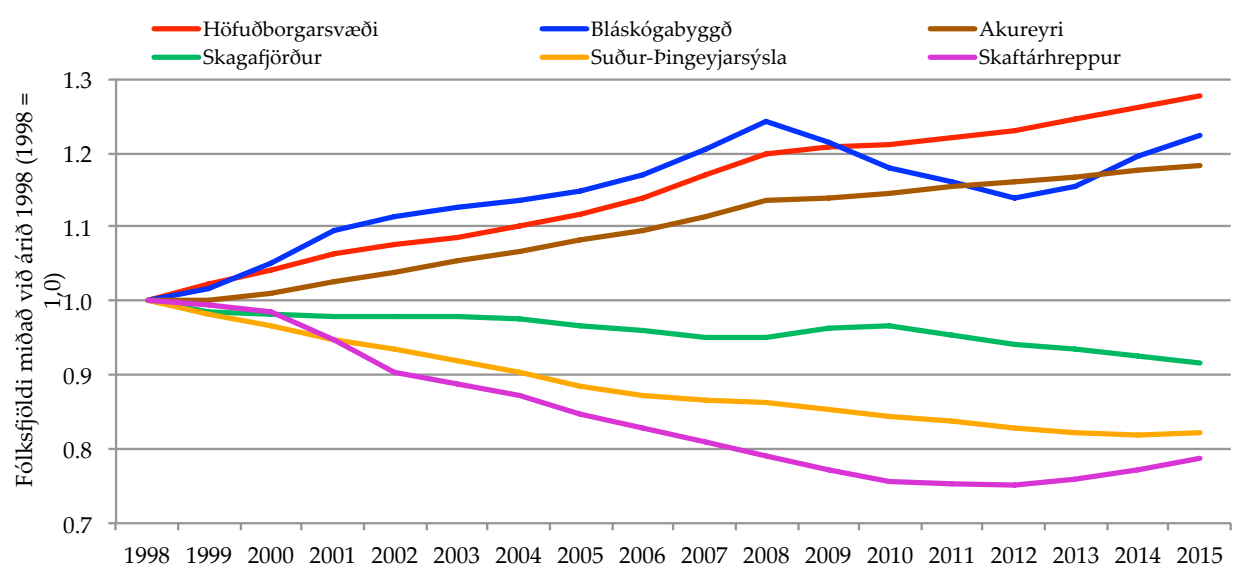

Mynd 7. Breytingar á íbúafjölda á búsetusvæðum viðmælenda miðað við fjölda ársins 1998.

Unnið úr gögnum Hagstofu Íslands (2017c).

Hálfstöðluð viðtöl (e. semi-structured interview) er ein mest notaða eigindlega rannsóknaraðferðin (e. qualitative research method) (Braun og Clarke, 2013; Kitchin og Tate, 2000). Í hálfstöðluðum viðtölum styðst spyrill við fyrirfram ákveðnar spurningar og fléttar pær inn í viðtalið. Leitast er við að hafa umræðuna opna og láta viðmælendur leiða samtalið eins og hægt er en gæta pess pó að leiða viðmælendur aftur að efninu ef pörf er á. Samtalið hófst á að spyrill kynnti sig og verkefnið og spurði síðan um hvort og hvernig ferðapjónustufyrirtækið sem viðmælandi starfaði hjá nýtti viðkomandi svæði, hvers konar ferðir um væri að ræða, fjölda ferðamanna á pess vegum og í hverju aðdráttarafl svæðisins væri fólgið. Að pví loknu voru pær virkjunarhugmyndir ræddar sem uppi eru á viðkomandi svæði og viðmælendur beðnir um að lýsa pví hvaða áhrif pær myndu hafa á starfsemi peirra. Pessi hluti viðtalanna er ekki kynntur í pessari grein heldur eingöngu seinni hluti viðtalanna par sem viðmælendur voru spurðir hvort peir teldu fyrirhugaðar virkjanir geta rýrt möguleika ferðapjónustunnar til eflingar byggðar. 
Viðtölin voru öll hljóðrituð og afrituð að pví loknu. Pau voru síðan greind og kóðuð og megin pemu dregin fram. Í beinum tilvísunum í kaflanum sem hér fer á eftir hefur stam og hik verið fjarlægt, auk pess sem aukaorðum hefur verið fækkað.

\section{Ferðapjónusta eða orkuframleiðsla sem bjargráð byggða?}

\subsection{Próun byggðar}

Flestir viðmælendur á landsbyggðinni höfðu áhyggjur af peirri miklu fólksfækkun sem hefur einkennt byggðapróun í landinu undanfarna áratugi. Meðal orsakavalda sem voru nefndir voru breytingar á atvinnuháttum, t.d. fækkun starfa í landbúnaði og í fiskvinnslu en líka breyttar kröfur um afpreyingu og pjónustu. Viðmælandi í Skaftárhreppi sagði:

Ég veit eiginlega ekki af hverju pað er fólksfækkun hér pví að mörgu leyti er allt til staðar hérna. Pað er fínn, góður skóli og mjög gott ípróttahús og bókasafn. [...] Petta er gott samfélag en svo náttúrlega skortir á petta sem menn vilja sækja svo mikið í, pað eru kaffihúsin og pað eru bíóin og petta.

Pegar viðmælandinn var spurður hvort hann teldi fólksfækkun vera áhyggjuefni í sveitarfélaginu svaraði hann:

Ef pú hefðir spurt mig um petta fyrir fjórum árum hefði ég sagt já, en ég myndi hins vegar segja nei í dag pví ferðapjónustan er bara að vaxa pað mikið... аð í raun og veru vantar bara fólk í störf og heilsársstörf hérna til pess að leysa pað.

Í Bláskógabyggð var fólksfjölgun í sveitarfélaginu undanfarin ár pökkuð annars vegar byggingarvinnu við skólahúsnæði og hins vegar nýsköpun í ferðapjónustunni: „Fólkið sem hefur verið að flytja núna í sveitarfélagið [hefur] bæði verið að vinna við skólann en svo líka varðandi nýsköpun í ferðapjónustu“.

Flestir viðmælendur voru á pví að pað væri helst ferðapjónustunni að pakka að viðsnúningur hefði orðið á byggðapróuninni. Dæmi um pá sýn má lesa úr orðum viðmælanda á Suðurlandi sem sagði:

Sum byggðarlög væru gjörsamlega.... ja, væru bara eiginlega í auðn ef pau væru ekki ferðamannastaður. Petta er að breytast t.d. eins og í Mývatnssveit eða Vík í Mýrdal, Öræfasveit... раð hefur hægt á fólksfækkuninni vegna pess að í sveitum víða eru að spretta upp gistihús hingað og pangað og eins og til dæmis ungt fólk sem var flutt á mölina, pað sér núna einhver tækifæri til að gera eitthvað. 
Ýmsir viðmælendur horfðu jákvæðum augum til framtíðar og var pað fyrst og fremst ferðapjónustan sem kveikti vonarneistann:

Ferðamennska hefur verið рað helsta sem hefur dregið úr fólksfækkun og jafnvel erum við farin að sjá núna merki um að... pað er að byrja að koma ungt fólk, bara út af ferðamennsku í Mývatnssveit sérstaklega og núna líka á Laugum.

Í Suður-Pingeyjarsýslu hefur orkuframleiðsla og fyrirhuguð stóriðja ekki síður haft jákvæð áhrif á búsetupróunina en ferðapjónustan. Viðmælandi í Pingeyjarsveit sagði:

Pað hefur verið fólksfækkun á Norð-Austurlandi eða í gömlu Pingeyjarsýslu. Pá hefur verið fólksfækkun í flestum sveitarfélögum undanfarin ár. Við væntum pess að nú sé viðsnúningur vegna verkefna á Bakka, en pað er náttúrlega fleira að gerast... Hér víða um sveitir er vonandi að draga úr eða hætta fólksfækkunin vegna pess að tækifærin í alls kyns ferðapjónustu eru að verða til staðar, eru að verða meiri.

Flestallir viðmælendur höfðu pá trú að ferðapjónustan væri sú atvinnugrein sem byði upp á mesta möguleika til tekjuöflunar og eflingar byggðar til framtíðar og töldu peir að greinin ætti eftir að vaxa enn frekar ef rétt yrði haldið á spilunum. Sérstaklega var horft til mikilvægis landsbyggðarinnar í pessu samhengi vegna nálægðar hennar við náttúruna - aðalaðdráttarafl landsins. Byggðirnar á jaðri hálendisins nytu jafnframt góðs af pví „að eiga ósnortin svæði... er eitthvað sem verður verðmætara og verðmætara fyrir okkur að eiga“. Margir ferðapjónustuaðilar bentu á að Gullni hringurinn (Pingvellir, Gullfoss og Geysir) og Suðurströndin væru um pað bil að ná polmörkum sínum og pá pyrfti ný svæði til að fara með ferðamenn á. Í pví sambandi væri Norðurland mjög mikilvægt: „Og pegar fer að prengja meira að... Gullna hringnum og á Suðurlandinu, og ég tala nú ekki um ef pað kemur beint flug á Norðurland, að pá yrði gríðarleg aukning á pessari leið“.

\subsection{Atvinnusköpun og tekjur}

Nánast allir viðmælendur komu inn á mikilvægi ferðapjónustunnar með tilliti til gjaldeyrissköpunar. Einn viðmælenda dró petta skýrt fram pegar hann sagði: „Ég veit nú ekki hvort pað er óumdeilt en pað... Við værum náttúrlega bara á hausnum ef við hefðum ekki alla pessa ferðamenn sko, pað er mjög einfalt sko“. Flestir viðmælendur voru jafnframt á pví að ferðapjónustan skapaði mörg störf í viðkomandi sveitarfélögum. Einn viðmælandi á Norðurlandi rifjaði upp pegar hann „stofnaði petta pínulitla fyrirtæki fyrir fimm árum síðan og hér vinna í dag yfir 70 manns í fullu starfi og eftir eða í lok pessa árs verða hérna um 140 manns í fullu starfi“. Ferðapjónustuaðili á 
Suðurlandi tók í sama streng: „Sko, ef við tökum Suðursveit og Öræfasveit á ársgrundvelli skapar petta litla fyrirtæki hér 30 ársstörf í pessum tveimur fámennu byggðarlögum“. Breytingin í pessa veru hefur verið sérstaklega mikil undanfarin ár og í sumum sveitarfélögum, eins og t.d. í Bláskógabyggð, var ferðapjónustan orðin ein mikilvægasta atvinnugreinin:

Рað er gríðarleg aukning sem hefur orðið á pessu svæði. Petta er orðin aðalatvinnugreinin hérna, petta er komið upp fyrir bæði landbúnað og garðyrkjuna. Ferðapjónustan er orðin númer eitt hjá okkur, auðvitað misjafnt eftir sveitarfélögum, pað er mest hérna uppi í Bláskógabyggð og meira eða minna hjá hinum líka. Рað er alveg gríðarleg breyting hérna undanfarin ár og algjör stökkbreyting síðastliðin tvö ár.

Ferðapjónustuaðili í Skaftárhreppi tók í sama streng:

Pessi mikli vöxtur sem hefur verið í ferðapjónustunni undanfarin ár hefur gert pað að verkum að fólk getur haldið áfram að búa á sínum stað og jafnvel er unga fólkið, sem var flutt á mölina, farið að koma heim aftur og pað er frábært að sjá. Pannig að ég myndi nú segja að ferðapjónustan hefur sannarlega eflt byggðina.

Aftur á móti var einnig bent á að mörg störf í ferðapjónustunni væru illa launuð: „Petta er láglaunasvæði, pað er stóra vandamálið ef fólk er að sækjast í einhver alvörulaun, og drifkrafturinn í ferðapjónustu og garðyrkjunni og allri svona verkamannavinnu eru orðnir útlendingar". Ekki voru allir sammála pví að störf í ferðapjónustu væru láglaunastörf. Eigandi afpreyingarfyrirtækis á Norðurlandi sagði í pví sambandi:

Við erum með hóp af vel menntuðu fólki sem sinnir skrifstofustörfum og pjónustustörfum hérna í fyrirtækinu og síðan erum við með mjög vel pjálfaða leiðsögumenn sem eru ekki láglaunafólk pannig að pessi umræða t.d. að öll ferðapjónustustörf séu láglaunastörf... pað á bara ekki við um petta fyrirtæki.

Viðmælendur töldu jafnframt flestir að með tilliti til atvinnusköpunar væri ferðapjónustan mun vænlegri en orkuframleiðsla „nema pá bara á uppbyggingartímanum". Viðmælandi á Suðurlandi bar saman atvinnusköpun vegna orkuframleiðslu og ferðapjónustu:

...Pjórsársvæðinu, petta eru ekkert margir sem vinna parna að staðaldri... kannski 10 manns... Auðvitað myndu virkjunarframkvæmdir koma með alveg gríðarlega mikla atvinnu 
inn í sveitarfélagið en nota bene, til hvað, fjögurra til sex ára á meðan á uppbyggingartíma stendur... Pannig að heilsársstörf sem eftir liggja til framtíðar eru kannski takmörkuð, ein til tvær stöður. Á meðan eitt blómlegt hótel í rekstri hefur að bera 30-40 starfsmenn.

Viðmælandi í Mývatnssveit benti á að ef tekið væri tillit til fórnarkostnaðar pá væri hann líka mun meiri pegar virkjað væri:

Svo eru hlutir eins og Bjarnarflagsvirkjun. Auðvitað skapar petta störf á uppbyggingartíma en petta er... rosalega mikill kostnaður, mikill fórnarkostnaður. Ef pú tekur alla pá fjármuni til að skapa bara tvö til prjú störf, pú veist pað væri svo miklu betra að bara búa til gróðurhús eða eitthvað svoleiðis í staðinn, ef pú gætir leyft pér að nota pessa fjármuni til að skapa annars konar atvinnu.

Fleiri tóku í sama streng eins og viðmælandi í Norðurpingi:

... svo getur maður aftur velt fyrir sér, 120 störf [á Bakka] plús einhver afleidd störf. Fjárfestingin er $\mathrm{x}$ í einhverju veldi sem ég hef ekki hugmynd um hver er en pað er einhver býsna há tala. Ég er sannfærður um pað að pað hefði verið hægt að búa til pessi 120 störf fyrir minni pening í ferðapjónustu... Væntanlega lægri laun, mögulega lægri laun, mögulega náttúrlega minna að gera í uppbyggingunni en sko, pað er mikilvægt að menn horfi svona á pessa hluti svolítið sko í samhengi.

Fórnir á peim verðmætum sem felast í náttúrunni og framtíðarverðmæti hennar voru einnig ræddar:

Ég held að pað sé mikilvægt fyrir okkur sem pjóð að í fyrsta lagi fara að viðurkenna og átta okkur á hvað náttúran er mikilvæg, af svo mörgum ástæðum. Náttúran hefur mesta aðdráttaraflið og skapar mestu tekjurnar fyrir pjóðarbúið en burt séð frá pví, ég held nú bara til frambúðar og framtíðar að eiga svona land og náttúru. [...] Og virkjanir, sko, pó að pær skili einhverjum fjárhagslegum ávinningi í einhvern takmarkaðan tíma pá bara líður sá tími, 30 eða 50 ár, og við sitjum uppi með óafturkræfar framkvæmdir.

Margir töldu að fjármagnið sem kemur úr ferðapjónustunni dreifðist meira á meðal manna en pað fjármagn sem kemur frá orkugeiranum: „Юað er enginn dreifing á fjármagninu í kringum orkuna pannig lagað séð... [ferðapjón- 
ustan] dreifir alla vega svolítið peningunum í kring, eins og ég kalla pað“. Margir viðmælendur komu inn á að einn af kostum ferðapjónustunnar væri að hún stuðlaði að betri nýtingu innviða og fjárfestinga sem nýttust einnig íbúum landsins:

Рað byggist upp hérna kerfi og infrastrúktúr fyrir pjóðfélagið sem er mjög erfitt að reka fyrir 300.000 manna samfélag pannig að með ferðamennskunni pá er svo margt... t.d. bara rekstur sundlauga í Reykjavík. Að fá milljón ferðamenn aukalega til pess að koma og borga sig inn í sundlaugarnar, pað gerir rekstrarkostnaðinn og býður upp á að pað sé hægt að halda og auka pjónustuna við innfædda og pá sem búa hérna allt árið.

Nokkrir viðmælendur bentu á að greinin færi í framtíðinni að skila enn meiri tekjum:

Umræðan í pjóðfélaginu hefur verið sú að ferðapjónustan sé ekki að skila nógum skatttekjum. Í fyrsta lagi pá er nú búið að setja virðisaukaskatt á frá áramótunum á pjónustuna og nú er ferðapjónustan að verða arðbær í fyrsta skipti í langan tíma, sem fer að skila auknum skatttekjum.

Lítill rekstraraðili á Norðurlandi ætlaði að gæta sín á pví að verða „ekki præll ferðaskrifstofa eða peirra sem eru að verða ríkir af pessu fyrir sunnan að selja bara ferðir". Hann vildi gæta pess að tekjurnar færu til hans sjálfs og fannst að aðrir í hans byggðarlagi ættu að hugsa eins pví pá yrði fjármagnið eftir í peirra heimabyggð.

Mörgum varð tíðrætt um pá miklu breytingu sem lengri ferðamannatími hefði haft í för með sér:

Á örfáum árum hefur petta breyst alveg ótrúlega... bara á fimm til sex árum hefur orðið algjör bylting í pví að reka ferðapjónustufyrirtæki vegna pess að tíminn hefur lengst, bæði bara high season, pað er orðið alveg frá maí og fram í október, bara alveg linnulaust.

Margir komu inn á að skortur væri á starfsfólki yfir sumartímann: „Hjá okkur starfar skólafólk og útlendingar... Málið er pað að pað er bara ekki nógu mikil framleiðsla á fólki til pess að standa undir allri pessari sumartraffík hérna sko“. Ferðapjónustuaðili á Norðurlandi kvartaði undan árstíðasveiflunni og hlakkaði til pegar vetrartraffíkin á Suðurlandi færi að skila sér norður:

Aðalvandinn er pessi árstíðasveifla en á móti kemur að við sjáum að pað er gríðarleg fjölgun á ferðafólki inn í Ísland pannig að tímaspurningin er sko 
hvenær færist petta út á land og ég held að pað sé að sumu leyti undir okkur sjálfum komið.

\section{3 Árekstrar orkuvinnslu við ferðapjónustuna}

Að mati flestra viðmælenda fara orkuvinnsla og ferðapjónusta illa saman: „Ég held að hún eigi mjög erfitt með að fara saman. Pað parf alla vega pá að stíga mjög varlega til jarðar“. Margir nefndu að: „petta eyðileggur ímynd Íslands og skerðir ferðapjónustuhagsmunina. Við ættum frekar að vanda til verka í uppbyggingu ferðapjónustu og slaka aðeins á með orkuna... orkufrekjuna“. Mörgum viðmælendum fannst orkuframleiðsla í págu stóriðju nú pegar vera búin að leggja undir sig nógu mikið af landi og í raun væri lítið eftir handa ferðapjónustunni:

...pá finnst mér við vera búin að króa pennan litla ósnortna hluta af hálendinu allhressilega inni... Pú ert með Kvíslaveitur, Hágöngulón, Eyjabakka eða ætlaði ég að segja Kárahnjúkavirkjun og svo náttúrlega Kröfluvirkjun í norðri en sem sagt petta er ekki orðin mjög stór spilda. Jú, auðvitað er petta stórt landsvæði en parna finnst mér að við purfum að hugsa í áratugum, ekki einhverjum mánuðum eða árum.

Ástæður pess að greinarnar fara illa saman að mati ferðapjónustuaðilanna voru fyrst og fremst að báðar nýta pær náttúruna sem auðlind en orkuframleiðslan rýrir gildi hennar til náttúruskoðunar fyrir ferðamenn. Virkjanirnar póttu pó ekki allar jafn slæmar og nefndu nokkrir Hellisheiðarvirkjun sem dæmi par sem hefði mátt gera mun betur. Viðmælandi í Reykjavík sagði:

Hengilssvæðið... mér finnst pað vera víti til varnaðar. Раð hefur alveg gríðarleg sjónræn áhrif og pau rök að pað komi í staðinn að menn geti farið og horft á einhverjar fallegar prívíddarsýningar í einhverju stöðvarhúsi eru náttúrlega bara algjörlega absúrd svar við náttúruspjöllum.

Nesjavallavirkjun pótti hins vegar skárri pví hún væri mun afmarkaðri:

Hellisheiðarvirkjun, ef pú berð hana saman við Nesjavallavirkjun, að pá er Nesjavallavirkjun miklu meira... contained, pað eru ekki pípur út um allt eins og petta hafi orðið fyrir einhverri sprengjuárás. Hellisheiðarvirkjun er bara eins og hún sé algjörlega stjórnlaus, pað eru bara pípur út um allt og lokaðir vegir.

Mörgum fannst mikilvægt að takmarka byggingu virkjana við ákveðin svæði og halda peim að minnsta kosti utan við hálendið: 
Við eigum að draga svona einhvern hring hérna... Og parna er ég sérstaklega að tala um óbyggðir, og hálendið og óbyggðir eins og pær ná niður að einhverjum byggðarmörkum og draga par stóra línu og segja „stofnum pjóðgarð“ eða segja „petta er svæði sem við ætlum að hugsa alveg sérstaklega vel um“. En, höldum áfram bara að virkja og nýta auðlindirnar bara fyrir neðan pessa línu.

Einnig var bent á að: „með hverri nýrri virkjun sem kæmi væri gengið á sérstöðu landsins og prengt að starfsemi ferðapjónustufyrirtækjanna“. Viðmælanda í Reykjavík fannst raforkuframleiðsla vinna gegn ferðapjónustunni: „Petta stangast mikið á, petta er bara eins og að ætla að vera á hvalveiðum í firðinum par sem pú ert í hvalaskoðun, pað gengur ekki upp, pað bara passar ekki saman".

Jafnframt var talið að markhópar ferðamannastaða breyttust ef virkjað yrði nálægt peim. Margir sögðust hafa minni áhuga á ferðamönnum sem kæmu prátt fyrir virkjanir, baráttan um pann markhóp væri mun harðari pví par væri meiri samkeppni. Eftir pví sem að sérstæða landsins minnkaði yrði erfiðara að fá pann náttúruáhugamenn hingað:

раð er alltaf að verða meira og meira í ferðapjónustunni trendið að gera eitthvað off the beaten track og að vera ekki alls staðar par sem allir eru og við eigum ekki að gera ferðapjónustuna einsleita, pá hættir fólk að koma og bara flest út og verður bara eins og annars staðar út um allt landið á sama veginum, pú veist, pá missum við petta.

Ljósmyndarahópar voru nefndir sem sérstaklega viðkvæmir fyrir virkjunarmannvirkjum: „Maður heyrir á peim... mjög neikvæðar umsagnir um pessi svæði og mannvirki. Ég heyri aftur á móti minna frá ferðamönnunum okkar að peir séu að forðast... en ég heyri pað náttúrlega frá ljósmyndurunum“.

Í Skagafirði eru Austari-Jökulsá og Vestari-Jökulsá, sem eru bestu ár landsins, jafnvel í Evrópu, til flúðasiglinga og er Jökulsá eystri sú eina á landinu par sem hægt er að fara í tveggja daga siglingu. Að mati viðmælenda í Skagafirði er stór hluti gistingar á svæðinu til kominn vegna flúðasiglinga. Ef pær virkjunarhugmyndir sem par eru uppi yrðu að veruleika myndu pær skerða eða útiloka möguleika til flúðasiglinga. Af pví höfðu flestir viðmælendur á svæðinu áhyggjur og höfðu orð á pví að ferðapjónustan á svæðinu væri ein samhangandi heild: „Petta er samtengt allt meira og minna“. Töldu ýmsir að pað hefði áhrif á aðra ferðapjónustu, eins og t.d. gistipjónustu, veitingastaði, hestaferðir og gönguferðir, ef flúðasiglingarnar hyrfu. 
Ég sé pað nú ekki fyrir mér að pað myndi hafa einhvern veginn bein áhrif hjá mér - nema petta, eins og ég var að segja, að petta er allt samhangandi. Og ef fólki fækkar í héraðinu pá ... að fólk hætti að koma í rafting og koma inn á... Pá auðvitað dregst allt saman. Maður getur bara séð petta, að petta er allt... Parna yrði kippt stoðum undan ferðapjónustunni í héraðinu með pessu.

Nefnt var að óvissa um hvar eða hvort yrði virkjað á nýjum svæðum hefði verið hamlandi fyrir próun ferðapjónustunnar. Menn voru hikandi að byrja á að skipuleggja ferðir um svæði par sem uppi eru hugmyndir um virkjanir vegna pess að öll fjárfestingin væri ónýt og vinnan og fjármagnið farin fyrir lítið ef svo yrði ákveðið að virkja. Pessi staða hafði að mati sumra viðmælenda hamlað próun ferðapjónustu á hálendinu:

Vandamálið í uppbyggingu í ferðapjónustu í dag er að hún er í gíslingu virkjana og pað er ekki hægt að segja hvernig maður sér fyrir sér uppbyggingu ferðapjónustu á neinum stað á hálendinu pví pað er enginn að fara að setja pening í petta á meðan hann veit ekki að hann hafi landið. Pú parft að vita að pú hafir petta land eins og pað er... eins lengi og pú parft. Á meðan pessi svæði eru í gíslingu virkjunarframkvæmda pá hugsar enginn um að byggja eitthvað upp, af pví pú veist að einn daginn gæti pað bara verið ónýtt. Fjárfestingin er bara út um gluggann! Раð er vandamálið, pað er enginn að horfa á Fjallabak, pað er enginn að horfa á hálendið í heild sinni og hugsa hvernig væri best að byggja petta upp í tengslum við ferðapjónustuna.

Annað dæmi var nefnt af Eldvörpum á Reykjanesi par sem ferðapjónustuaðili hafði verið með gönguferðir frá Reykjanesvita, um Eldvörp og paðan yfir í Bláa lónið.

Nú er pessi ferð eiginlega ónýt. Núna er búið að gefa framkvæmdaleyfi... Ég er að fara á ferðaráđstefnu í Berlín í mars. Á ég að nenna að selja pessa ferð? Рað er rosaleg orka og peningur sem fer í... og ég er búin að eyða fullt af krafti í petta svæði ...pá er búið að eyðileggja pað núna fyrir mér. Alla pá markaðssetningu, pá vinnu og allt pað sem ég lagði í Eldvörpin... Ég er að prenta út eitthvað efni og gera heimasíðu og maður er bara að eyða pening, tíma og orku... Petta dregur úr manni... Algjörlega. 
Flestir viðmælendurnir töldu að orkuframleiðsla í landinu væri nægjanleg og að ekki væri ástæða til að virkja frekar. Sumir bættu við: „Nema til komi rafvæðing bíla- eða skipaflota landsmanna“. Ferðapjónustuaðili á höfuðborgarsvæðinu sagði:

Ég held að pað sé full ástæða til að hægja á. Og ég er ekki að segja að pað purfi endilega að hætta. Miðað við uppganginn sem hefur verið pá sé full ástæða til að hægja verulega á ferlinu í langan tíma. Og bara meta... út frá fleiri sjónarmiðum hvort við purfum á landinu að halda fyrir eitthvað annað. Ef við horfum á Blöndulón, pað hefur kannski ekkert gríðarlega mikil áhrif á umhverfið, en pað hefur samt áhrif og ef við ætlum að horfa til 50 ára, viljum við endilega pessi áhrif? Við erum að fara alltof hratt að mínu mati.

\subsection{Farsæl sambúð ferðapjónustu og orkuframleiðslu}

Pau sjónarmið komu fram hjá nokkrum að pað væri „sjálfsagt að nýta auðlindir landsins eins og til pyrfti“. Nokkrir viðmælendur voru á pví að orkuframleiðsla og ferðapjónusta væru til pess fallnar að efla og styrkja byggð í landinu og litlir eða engir árekstrar væru parna á milli: „Já, auðvitað getur petta [orkuframleiðsla og ferðapjónusta] farið saman, að sjálfsögðu getur petta alveg unnið saman eins og landbúnaður og sjávarútvegur“. Einn taldi sig ekki hafa „efni á pví sem ferðapjónustuaðili að tala aðrar atvinnugreinar niður“. Einnig var bent á aðdráttarafl grænnar orkuframleiðslu:

Sko, í peim ræðum sem ég held með mínum gestum pá hrósa ég okkur Îslendingum fyrir græna orku og ég grobba mig af pessu. Ég tel að við eigum að hreykja okkur af pví að vera að framleiða græna orku fram yfir aðra.

Ferðapjónustuaðili í Reykjavík sagði: „ég sé engar hættur... ekki fyrir stærsta hlutann sem er að koma hérna og t.d. almenningur í Ameríku er ekkert að spá í pað hvort einhver einn hérna lítill foss, tiltölulega ópekktur, hefur minnkað vegna pess að hérna eitthvað uppistöðulón var gert“. Virkjanirnar sem slíkar voru af sumum taldar hafa ákveðið aðdráttarafl:

Раð er fullt af ferðamönnum að skoða stífluna fyrir austan. Gufan og heita vatnið heillar líka alveg rosalega, fólk er rosalega spennt fyrir að virkja og hvernig heita vatnið er nýtt. petta er bara... ég held að pað fari alveg rosalega margir á Nesjavelli og Hellisheiði til að skoða.

Sumir viðmælendur sögðust reglulega fara í gestastofur virkjana með viðskiptavini sína: 
Jú, peim finnst mjög áhugavert hvernig við erum að nýta orkuna. Og bæði pessar... eins og í Búrfellsvirkjun, pað er mjög skemmtileg sýning par. Og síðan hefur líka vakið mikla athygli sem Eiður og hans menn eru að gera parna fyrir norðan, allar pessar smávirkjanir út um allt land, virkja bæjarlækinn.

Fleiri bentu á að gera mætti enn betur á pví sviði með pví að kynna betur litlar heimavirkjanir:

Mér finnst einhvern veginn ferðapjónusta, sérstaklega hérna úti á landi, hjá til dæmis bændum sem eru að reka pessi einka litlu hitaveitur... peir mættu alveg auglýsa meira og selja og láta fólk vita hvernig peir virkja orkuna. Petta er svona... fólk er rosalega spennt fyrir pessu alltaf.

Einn viðmælandi í Bláskógabyggð rifjaði upp farsæla sambúð atvinnugreina par sem ferðapjónusta og landbúnaður (tómatarækt í raflýstum gróðurhúsum) sem stórnotandi rafmagns færu vel saman og hefðu í raun styrkt hvort annað:

Til dæmis gróðurhúsunum par sem farið er að opna pau, jafnvel bjóða upp á veitingar inni í peim eins og t.d. inni í Reykholti. Par náttúrlega fer saman mikil raforkunotkun, sem er náttúrlega í lýsingu, ásamt ferðapjónustu. Petta t.d. bara... pessi hugmynd er algjör snilld að mínu mati en parna er mikið notað af rafmagni, rafmagnskostnaðurinn var að sliga hann, en svo kemur ferðapjónustan. Pá er hægt að sýna fram á pað hvernig ferðapjónustan náði að hjálpa til við að snúa rekstrinum á rétta braut.

Viðmælendur voru sammála pví að heimsóknir í virkjanir væri „ekki tilgangur ferðarinnar nema kannski hjá fámennari hóp" heldur væru pær meira „Svona add-on/rjóminn ofan á".

Nokkrir töldu aukna ferðamennsku og aukna raforkuframleiðslu geta farið saman „á vissum svæðum“ og horfðu pá fyrst og fremst til vegalagningar vegna virkjunarframkvæmda. Pá var einnig mikilvægt, eftir að búið væri að virkja, að veginum væri haldið opnum yfir vetrartímann. Flestir voru pó á pví að við pyrftum „alltaf að passa okkur á pví að taka ekki of mikið af víðerninu í burtu. Pví pað prengir alltaf að, eftir pví sem við tökum meira, pað er alveg morgunljóst, sko“. Einnig var sagt: „Ég er ekkert á móti pví að pað eigi að nýta eitthvað af pessu en ekki of mikið, pað verður bara alltaf að reyna að bremsa og segja hingað og ekki lengra“. 
Sumir viðmælendur bentu á að pað væri munur á hvaða leið væri farin í orkuframleiðslu og taldi vatnsorkuna ekki skemma svo mikið fyrir ferðapjónustunni en vindmyllur myndu hins vegar hafa mikil neikvæð áhrif á landslagið:

Á meðan við eigum vatnsaflsvirkjanir sem renna bara óbeislaðar, sem hægt er að framleiða í sátt og samlyndi við guð og menn, pá finnst mér pað ákjósanlegri kostur heldur en vindmyllugarðar hér og par sem skemma útsýnið.

Einn viðmælandi á Norðurlandi talaði um að ferðapjónustan gæti í raun prifist með hvaða annarri atvinnugrein sem er: „Uppbyggingin í ferðapjónustu er oft hliðarafurð af einhverju öðru. Hún er hliðarafurð af sjávarútvegi, hún er hliðarafurð af orkuuppbyggingu og hún er hliðarafurð af hinu ýmsu. Ferðapjónustan er náttúrlega pannig að hún getur lagað sig að nánast öllu“. Einn viðmælandi í Skaftárhreppi lagði áherslu á að báðar greinarnar væru viðkvæmar og óparfi að stilla peim upp eins og andstæðum pólum:

Ég myndi kannski bara ekki stilla pví upp pannig að petta séu einhverjir andstæðir pólar sko. Við vitum að pessi áliðnaður eða stóriðja, pað er brothættur bisness út frá pví hvernig markaðir próast... Ferðapjónustan er enn pá brothættari atvinnugrein, pað parf ekki mikið úr lagi að ganga til pess að pað verði algjört hrun í ferðapjónustu á Íslandi. Við getum bara ímyndað okkur annaðhvort náttúruhamfarir eða... Skaftáreldar stóðu nú yfir í rúmlega heilt ár og lömuðu nánast alla Norður-Evrópu... 1783-4 ... Нvað ef pað gerist? Hvað yrðu mörg hótel hérna komin á hausinn á annarri viku, ha?

Viðmælandi á Norðurlandi taldi orkuframleiðslu betri leið fyrir landið í heild sinni en ferðapjónustu: „Ábyggilega raforka betri... Einhvern veginn er pað kannski minna áberandi að framleiða rafmagn heldur en... troðandi milljónum manna hér".

Nokkrir viðmælendur bentu á að samtal og samstarf orkuframleiðenda og ferðapjónustunnar mætti vera meira og betra en pað er nú og fannst einum viðmælanda „framkvæmdaraðilar mega fá skömm í hattinn fyrir að hafa ekki nýtt tækifærið til að vingast meira við ferðapjónustuna." Annar viðmælandi sagði að meðal ferðapjónustunnar væri:

...alveg skýr vilji til pess að ræða betur saman. Раð er alla vega af okkar hálfu, Samtökum ferðapjónustunnar og pað er eitthvað málping um að efla samtalið á milli Landsvirkjunar 
og ferðapjónustunnar. Ég hef enga trú á öðru en að pessir aðilar geti unnið saman og menn purfa bara að nálgast petta á jafningjagrunni... Auðvitað eru alltaf öfgar inn á milli, pað eru alltaf einhverjir sem að hata allt og vilja helst bara fara allt labbandi eða á reiðhjólinu en við verðum bara að finna hinn gullna meðalveg.

Ýmis dæmi voru nefnd par sem petta samtal hefði átt að vera betra, eins og t.d. við byggingu Kárahnjúkavirkjunar:

Par er kominn beinn og breiður vegur en notagildi ferðapjónustunnar á Kárahnjúkasvæðinu eru mjög takmarkað vegna pess að samtal ferðapjónustunnar og byggingaraðilanna parna var nánast ekkert.

Viðmælandi á Norðurlandi hrósaði umgengni virkjunaraðila vegna Kárahnjúkavirkjunar en vissulega pýddi svona stórframkvæmd röskun á náttúrunni: „Юað er gengið rosalega vel frá öllu en maður sér að petta er gert... Petta eru mannvirki af manna höndum, sko, petta er ekki sko pessi ..." og leitaði að orðinu ósnortin náttúra til að botna setninguna.

Ferðapjónustuaðila í Reykjavík fannst upplýsingaflæði frá orkuframleiðendum til ferðapjónustunnar mætti vera betra:

Ég kom parna [Nesjavallaleið] núna í vetur og pá var búið að setja niður skilti og ég held að pað tengist pessu að pað varð parna slys par sem fólk keyrði á pípuna, pað kom gat á hana. En í staðinn fyrir að reyna að varna pví... að setja upp vegrið eða eitthvað svoleiðis, pá koma bara lokanir. Og parna er dæmi par sem ferðapjónusta og virkjunarkostur fer mjög vel saman.

Ferðabjónustuaðilar á Norðurlandi sem voru með norðurljósaferðir kvörtuðu undan Kröfluvirkjun og einn nefndi að hann hefði séð gervitunglamyndir sem sýndu að Krafla gæfi frá sér meiri birtu í janúar heldur en Húsavík. Peir vonuðu að petta samtal yrði betra við hönnun Peistareykjavirkjunar. Viðmælendum varð tíðrætt um mikilvægi pess að huga að lýsingu virkjunarinnar til að eyðileggja ekki möguleika á nýtingu vegarins sem byggður var vegna hennar til norðurljósaferða.

Og við förum pað margar norðurljósaferðir frá Mývatnssveit að fara eitthvað í nágrenni við Kröflu kemur ekki til greina, pað er gríðarleg ljósmengun frá Kröflu. Og ef Peistareykir eiga að vera hannaðir árið 2016 með jafn mikla ljósamengun, pá verða Peistareykir ekki staður, prátt fyrir beinan, breið- 
an og mokaðan veg og í rauninni góða uppbyggingu, fyrir ferðapjónustu. Pá verður petta ekki staður fyrir norðurljósafarpega.

Nokkrir viðmælendur voru á pví að greinarnar ferðapjónusta og orkuframleiðsla gætu „alveg farið saman ef menn eru tilbúnir að tala saman og vinna saman og taka tillit hver til annars. En ef menn gera pað ekki, pá er petta vonlaust saman... alveg. Og pá er pað ferðapjónustan sem víkur“.

Sumir töldu ferðapjónustu og raforkuframleiðslu „hvort tveggja vera umhverfisskemmandi“ og fram komu pau sjónarmið аð pað pyrfti að vernda náttúruna fyrir báðum greinunum: „Mér finnst að við eigum að vernda... mér finnst að pað eigi að vera landslagsheildir sem við bara ákveðum að við ætlum ekki að snerta, hvorki fyrir ferðapjónustu né virkjanir. Nokkrir viðmælendur komu inn á að móta pyrfti skýra stefnu fyrir ferðapjónustuna og fannst sumum „stýring á ferðamönnum vera mjög léleg á Íslandi og engin hugsun í pví hvernig við erum að gera pað“. Einnig var nefnt að gera mætti sambærilega áætlun fyrir ferðapjónustuna eins og rammaáætlun er fyrir orkuframleiðslu í landinu:

Mikilvægt að gera einhvers konar landnýtingaráætlun út frá ferðapjónustunni líka, svona rammaáætlun fyrir ferðapjónustuna. Par sem horft væri betur inn í svæðin og hvernig væri hægt að hafa pau fyrir ferðapjónustuna, gönguferða, hjólaferða, hestaferða, hvers konar, jeppaferða eða hvað við viljum hafa pað. Og eða pá hins vegar til alfriðunar... eða hluta. Рað parf að fara að horfa á pessa hluti heildrænt og spá hvað við viljum gera með ákveðin svæði.

\section{Umræður og ályktanir}

Með vaxandi mikilvægi ferðapjónustunnar hvað atvinnusköpun og útflutningsverðmæti varðar hefur fegurð náttúrunnar fengið aukið verðgildi og pungi umræðunnar um verndun hennar andspænis orkuvinnslu um leið aukist. Margar fyrirhugaðar virkjanir eru nálægt náttúruskoðunarstöðum, og par sem flestir ferðamenn koma til landsins til skoða náttúruna (Ferðamálastofa, 2015) töldu margir ferðapjónustuaðilar sem rætt var við í pessari rannsókn að frekari uppbygging virkjana myndi rýra möguleika ferðapjónustunnar til að efla byggð í landinu. Töldu peir flestir að svæðin yrðu minna áhugaverð til náttúruskoðunar ef par yrðu reistar virkjanir vegna pess að orkumannvirki skera sig úr í lítt snortinni náttúru og pau hafi par með neikvæð áhrif á aðdráttarafl staðanna. Að peirra mati minnkar við pað virði auðlindarinnar sem náttúruferðamennskan byggist. Með tilvísun til líkans Ritchies og Crouch (2003) má pví segja að ferðapjónustuaðilar telji að virkj- 
anir myndu rýra grundvallarauðlindir ferðapjónustunnar og par af leiðandi draga úr samkeppnishæfni áfangastaðanna sem peir gera út á. Margir töldu jafnframt að ímynd Íslands sem villtrar, óspilltrar og framandi náttúru væri stefnt í hættu, en ímynd er einn af áhrifapáttum á val áfangastaðar (Ritchie og Crouch, 2003). Margir bentu á mikilvægi pess að horfa til framtíðar í pessu tilliti. Рað er í góðu samræmi við niðurstöður fræðimanna á pessu sviði, sem benda á að víðerni og lítt snortin svæði séu á hverfanda hveli í heiminum og verðmæti peirra sem auðlindar fyrir ferðapjónustuna eigi eftir að aukast með hverju ári (sjá t.d. Hall og Frost, 2009; Talbot, 1998).

Ísland hefur mikið aðdráttarafl fyrir pá ferðamenn sem ferðast til að skoða lítt spillta náttúru (Anna Dóra Sæpórsdóttir, 2010; Unnur Birna Karlsdóttir, 2013) meðal annars vegna víðerna sem pekja rúmlega priðjung landsins (Rannveig Ólafsdóttir og Micael Runnström, 2010; Umhverfisstofnun, 2009). Rannsóknir meðal ferðamanna hér á landi hafa leitt í ljós að víðerni hafa mikið aðdráttarafl fyrir pá, sér í lagi fyrir pá sem ferðast um hálendið (sjá t.d. Anna Dóra Sæpórsdóttir, 2012; Anna Dóra Sæpórsdóttir, Birgitta Stefánsdóttir og Porkell Stefánsson, 2015). Hlutfallslegir yfirburðir Íslands og markhópar geta breyst ef gengið er um of á lítt spillta náttúru og víðerni. Fleiri ríki á norðlægum slóðum hafa upp á stórbrotna náttúru að bjóða pó að ýmist séu par ummerki manna algengari eða fjarlægð frá pjónustu meiri en hér. Ef markaðsblandan breytist með rýrnun víðerna og lítt spilltrar náttúru gæti Ísland hætt að höfða til peirra sem gera mestar kröfur um slíkt.

Í mörgum af peim viðtölum sem tekin voru við ferðapjónustuaðilana kom fram að peir gerðu sér grein fyrir að ferðapjónustan sjálf gæti einnig haft neikvæð áhrif á náttúruna, rétt eins og orkuvinnsla og orkunýting. Pað er enda vel pekkt innan ferðamálafræðinnar að ferðamannastaðir próast og breytast og að ferðapjónustan, eins og hver önnur atvinnugrein sem byggist á auðlindanýtingu, gengur á auðlindina, sem í pessu tilfelli er lítt spillt náttúra. Með pví móti pá eyðileggur hún fyrir sjálfri sér eða, eins og Krippendorf (1982) orðaði рað, ,"tourism destroys tourism".

Neikvætt viðhorf flestra viðmælenda í pessari rannsókn til orkuvinnslu verður hins vegar að skoða með hliðsjón af pví að mögulega ofmeti peir í huga sér sjónræn áhrif virkjana, samanber rannsókn Priestleys og Evans (1996). Nokkrir viðmælendur sögðust ekki hafa áhyggjur af sambúð orkuvinnslu og ferðapjónustu, sérstaklega ef meiri samvinna og betra samtal yrði par á milli en nú er. Nú pegar eru svæði hér á landi par sem greinarnar prífast saman og mögulega geta pær farið saman á fleiri svæðum. Rannsókn sem gerð var meðal ferðamanna í nágrenni Blönduvirkjunar leiddi í ljós að 67\% ferðamanna segja virkjunina ekki hafa áhrif á áhuga sinn á pví að ferðast um svæðið og flestum, eða 89\% ferðamanna, fannst svæðið náttúrulegt prátt fyrir virkjunina og meðfylgjandi mannvirki (Anna Dóra Sæpórsdóttir, Anna Mjöll Guðmundsdóttir og Porkell Stefánsson, 2017). 
Viðmælendur í pessari rannsókn töldu ferðapjónustuna vera björtustu vonina til að efla atvinnulíf í landinu og pá sérstaklega á landsbyggðinni. Рað viðhorf samræmist vel tóninum í sóknaráætlunum landshlutanna (Вyggðastofnun, 2015) og er algengt viðhorf meðal stjórnenda í íslensku atvinnulífi (Viðskiptaráð Íslands, 2011). Í sóknaráætlunum og könnun meðal stjórnenda í atvinnulífinu kemur einnig fram að nýta skuli orkuauðlindir til pess að efla iðnað, pótt stóriðja sé ekki ofarlega á blaði heldur smærri og arðbærari verkefni.

Árstíðasveiflur í komu ferðamanna til landsins hafa minnkað á örfáum árum, sem gerir atvinnugreinina stöðugri og arðvænlegri en áður. Meira er pví en áður um heilsársstörf í ferðapjónustu en pó sérstaklega á höfuðborgarsvæðinu og á Suðurlandi par sem vetrarferðamennska hefur vaxið hratt undanfarin ár. Vetrarferðamennskan hefur hins vegar enn sem komið er, ekki skilað sér nema að litlum hluta annars staðar á landsbyggðina og störf í ferðapjónustu par pví enn mjög árstíðabundin.

Víða um land er skortur á húsnæði helsta hindrunin fyrir pví að nýtt fólk geti sest að á staðnum. Ferðapjónustan er ein helsta ástæðan fyrir pessum húsnæðisskorti víða á landsbyggðinni en mest af pví húsnæði sem var áður tómt er nú leigt til ferðamanna og er sums staðar lítið sem ekkert af húsnæði á lausu fyrir pá sem vilja setjast að í dreifbýlinu. Ferðapjónustan eflir pví í senn byggðir með pví að skapa störf en hindrar jafnframt fasta búsetu peirra sem vilja setjast að úti á landi. Sum sveitarfélög hafa nú sett reglur um hlutfall húsnæðis sem leigja má til ferðamanna til að sporna við pessari próun.

Að mati margra viðmælenda hefur verið farið of geyst í uppbyggingu virkjana og orkuframleiðslu til að hægt sé að sjá að pað reynist pjóðinni vel. Arðsemi virkjunar- og stóriðjuframkvæmda er að sumra mati ekki nægilega mikil og peir telja að tiltölulega fá störf verði til fyrir mikla fjárfestingu í virkjununum sjálfum. Viðmælendur bentu jafnframt á að ekkert öryggi væri fyrir pví að orkan sé nýtt á viðkomandi svæði og pví að par yrðu til störf vegna orkuframleiðslu. Eins hafa tekjur af virkjunum ekki alltaf farið til sveitarfélaga sem verða fyrir umhverfisröskunum. Aðeins sveitarfélagið par sem stöðvarhús virkjunar er staðsett fær fasteignagjöld vegna virkjunarmannvirkja en sveitarfélög par sem uppistöðulón, stíflur eða raflínur eru reistar hafa ekki fengið slíkar tekjur. Pví getur komið fyrir að sveitarfélög sem verða fyrir neikvæðum ytri áhrifum vegna orkuvinnslu, til dæmis vegna rasks á náttúru, fái ekki neinar bætur (Hagfræðistofnun, 2015). Á pessu var pó gerð ákveðin breyting árið 2016 pegar dómur féll í Hæstarétti sem kveður á um að greiða beri fasteignagjöld af vatnsréttindum. Orkan er gjarnan notuð í öðru sveitarfélagi en hún er framleidd í og pví getur farið svo að virkjun skapi fá langtímastörf í framleiðslusveitarfélaginu. Mörg störf skapast pó á framkvæmdatíma en pað er pá oftast aðkomufólk sem vinnur pau. Eins og fram hefur komið, er grunnforsenda pess að íbúar séu sampykkir virkjun gjarnan 
sú að hún skapi langtímastörf í sveitarfélaginu (Guðbjörg Andrea Jónsdóttir og Hafsteinn Einarsson, 2016). Vandamál af svipuðum toga pekkjast einnig i ferðapjónustu, par sem fyrirtæki með starfsemi á höfuðborgarsvæðinu, sem selja t.d. ferðir vítt og breitt um landið, skilja eftir sig ýmiss konar rask en tekjur vegna starfseminnar skila sér að takmörkuðu leyti til svæðisins par sem auðlindina er að finna. Einnig starfar stór hluti vinnuaflsins í ferðapjónustu á landsbyggðinni par tímabundið en á fasta búsetu annars staðar. Tekjur pess skila sér pví ekki nógu vel sem útsvar til sveitarfélaganna par sem ferðamennirnir eru (Vífill Karlsson, 2017). Ekki komu pó margir viðmælendur inn á petta atriði í viðtölunum pó að nokkrir hafi nefnt pað og haft áhyggjur af. Verið er að vinna að leiðum til að bæta skattkerfið í kringum báðar pessar atvinnugreinar pannig að pær skilji eftir sig meira af tekjum í sveitarfélögunum par sem starfsemin fer fram og áhrifanna af henni gætir (Atvinnuvega- og nýsköpunarráðuneytið og Samtök ferðapjónustunnar, 2015). Viðhorf til pessara greina yrði væntanlega jákvæðara ef íbúar svæða gætu séð raunverulegan hag fyrir nærumhverfi sitt í að nýta staðbundnar auðlindir.

Í viðtölunum kom jafnframt fram að erfitt væri að fara í fjárfestingar í ferðapjónustu vegna óvissu um hvar verður virkjað í framtíðinni. Ferðapjónustuaðilar hikuðu jafnvel við að skipuleggja og markaðssetja ferðir um svæði par sem mögulega yrði virkjað síðar, í ljósi pess að peirri fjárfestingu væri pá kastað á glæ. Pessi atriði draga Ritchie og Crouch (2003) fram í líkani sínu og varða pau mikilvægi pess að stýra áfangastöðum, móta stefnu, gera áætlanir og próa pá til að stuðla að samkeppnishæfni peirra.

Pessi rannsókn gefur ekki tilefni til að álykta hvort að ferðapjónusta og virkjanir fari saman eða ekki, heldur varpar hún einungis ljósi á sýn ferðapjónustuaðila á fyrirhuguðum virkjunarsvæðum til slíkra hugmynda. Ekki er heldur gert tilraun til að svara pví hvort að betra sé fyrir pjóðarhag að virkja eða stunda náttúruferðamennsku. Pó er ljóst að flestir ferðapjónustuaðilar sem rætt var við telja að samkeppnisyfirburðir Íslands felast í pví að halda náttúrunni eins ósnotinni og að með pví móti nýtist ferðapjónustan sem best til að efla byggðir í landinu. Betri samvinna og samtal milli ferðapjónustunnar og virkjunaraðila gæti hins vegar minnkað eða komið í veg fyrir árekstra milli greinanna, t.d. með pví að taka tillit til framtíðarvirðis svæða fyrir ferðapjónustu, með hönnun mannvirkja og ef farið er eftir niðurstöðum rammaáætlunar með tilliti til virkjana í verndarflokki sem dregur úr óvissu um hvort virkjað verður. 


\section{Heimildir}

Anna Dóra Sæpórsdóttir (2010). Planning nature tourism in Iceland based on tourist attitudes. Tourism geographies, 12, 25-52. doi: 10.1080/14616680903493639

Anna Dóra Sæpórsdóttir (2012). Ferðamennska á miðhálendi Íslands: Staða og spá um framtíðarhorfur. Reykjavík: Land- og ferðamálafræðistofa, Líf- og umhverfisvísindadeild Háskóla Íslands.

Anna Dóra Sæpórsdóttir (2014). Preserving wilderness at an emerging tourist destination. Journal of Management and Sustainability, 4(3), 65-78. doi: 10.5539/jms.v4n3p65

Anna Dóra Sæpórsdóttir, Anna Mjöll Guðmundsdóttir og Porkell Stefánsson (2017). Áhrif Blönduvirkjunar á upplifun ferðamanna. Reykjavík: Land- og ferðamálafræðistofa, Líf- og umhverfisvísindadeild Háskóla Íslands.

Anna Dóra Sæpórsdóttir, Birgitta Stefánsdóttir og Porkell Stefánsson (2015). Viðhorf ferðamanna til nokkurra virkjana í3. áfanga rammaáætlunar. Reykjavík: Land- og ferðamálafræðistofa, Líf- og umhverfisvísindadeild Háskóla Íslands.

Atvinnuvega- og nýsköpunarráđuneytið og Samtök ferðapjónustunnar (2015). Vegvísir ferðapjónustunnar. Sótt 2. júní 2017 á http://www.saf.is/wp-content/uploads/vegvisir_ okt_2015.pdf.

Ásgeir Jónsson og Sigurður Jóhannesson (2011). Mat á arðsemi orkusölu til stóriðju: Önnur áfangaskýrsla. Reykjavík: Fjármálaráðuneytið.

Berg, B. L. (2006). Qualitative research methods for the social sciences. London: Pearson International Edition.

Bergmann, A., Colombo, S. og Hanley, N. (2008). Rural versus urban preferences for renewable energy developments. Ecological Economics, 65, 616-625. doi: 10.1016/j. ecolecon.2007.08.011

Braun, V. og Clarke, V. (2013). Successful qualitative research. London: Sage.

Briedenhann, J. og Wickens, E. (2004). Tourism routes as a tool for the economic development of rural areas: Vibrant hope or impossible dream? Tourism Management, 25, 71-79. doi: 10.1016/S0261-5177(03)00063-3

Byggðastofnun (1999). Byggðir á Íslandi: Aðgerðir íbyggðamálum. Reykjavík: Byggðastofnun.

Byggðastofnun (2015). Sóknaráætlanir. Sótt 17. október 2016 af http://www.byggdastofnun. is/is/byggdaaaetlun/soknaraaetlanir

Bylgja Árnadóttir, Guðbjörg Andrea Jónsdóttir og Hafsteinn Einarsson (2016a). Íbúafundur um samfélagsleg áhrif virkjana í Skaftárhreppi. Reykjavík: Félagsvísindastofnun Háskóla Íslands.

Bylgja Árnadóttir, Guðbjörg Andrea Jónsdóttir og Hafsteinn Einarsson (2016b). Íbúafundur um samfélagsleg áhrif virkjana í Skagafirđi. Reykjavík: Félagsvísindastofnun Háskóla Íslands.

Bændasamtök Íslands (2010). Hagtölur landbúnaðarins 2010. Reykjavík: Bændasamtök Íslands.

Castree, N. (2005). Nature. London: Routledge.

Castree, N. og Braun, B. (2001). Social nature: Theory, practice, and politics. London: Wiley-Blackwell.

Contini, C., Scarpellini, P. og Polidori, R. (2009). Agri-tourism and rural development: The Low-Valdelsa case, Italy. Tourism Review, 64(4), 27-36. doi: 10.1108/16605370911004557

Eyping (2015). Sóknaráxtlun fyrir Norđurland eystra 2015-2019. Sótt 17. október 2016 af https://www.byggdastofnun.is/static/files/Soknaraaetlun/2015-19/soknaraaetlun-nordurlands-eystra-2015-2019.pdf

Ferðamálastofa (2015). Ferðapjónusta á Íslandi i tölum. Sótt 2. september 2016 af http://www. ferdamalastofa.is/static/files/ferdamalastofa/Frettamyndir/2015/mai/ferdatjon_i_tolun_15.pdf 
Ferðamálastofa (2017). Ferðamenn um Keflavíkurflugvöll. Sótt 25. janúar 2017 af http:// www.ferdamalastofa.is/is/tolur-og-utgafur/fjoldi-ferdamanna/talningar-ferdamalastofu-i-flugstod-leifs-eirikssonar

Félagsvísindastofnun (2014). Viðhorf Íslendinga til ferðapjónustu. Unnið fyrir Ferðamálastofu. Reykjavík: Félagsvísindastofnun Háskóla Íslands.

Guðbjörg Andrea Jónsdóttir og Hafsteinn Einarsson (2016). Íbúafundur um samfélagsleg áhrif virkjana i neðri hluta Pjórsár. Reykjavík: Félagsvísindastofnun Háskóla Íslands.

Gunnar Pór Jóhannesson og Edward H. Huijbens (2010). Tourism in times of crisis: Exploring the discourse of tourism development in Iceland. Current Issues in Tourism, 13(5), 419-434. doi: 10.1080/13683500.2010.491897

Hafsteinn Einarsson (2016). Djóðmálakönnun: Unnið fyrir faghóp um samfélagsleg áhrif virkjana. Reykjavík: Félagsvísindastofnun Háskóla Íslands.

Hagfræðistofnun (2005). Djóðhagsleg áhrif álverksmiðju Fjarðaáls á Reyðarfirði. Reykjavík: Hagfræðistofnun.

Hagfræðistofnun (2015). Auðlindarenta og nærsamfélagið. Reykjavík: Hagfræðistofnun.

Hagstofa Íslands (2016a). Afkoma landbúnaðarins. Sótt 19. ágúst 2016 af https://hagstofa.is/ talnaefni/atvinnuvegir/landbunadur/afkoma-landbunadarins/

Hagstofa Íslands (2016b). Afli og ráđstöfun. Sótt 2. september 2016 af https://hagstofa.is/ talnaefni/atvinnuvegir/sjavarutvegur/afli-og-radstofun/

Hagstofa Íslands (2016c). Mannfjöldi. Sótt 19. ágúst 2016 af https://hagstofa.is/talnaefni/ ibuar/mannfjoldi/

Hagstofa Íslands (2016d). Vinnumarkaður. Sótt 19. ágúst 2016 af https://hagstofa.is/talnaefni/samfelag/vinnumarkadur/vinnumarkadur/

Hagstofa Íslands (2017a). Fjöldi launpega 2008-. Sótt 29. janúar 2017 af http://px.hagstofa. is/pxis/pxweb/is/Atvinnuvegir/Atvinnuvegir_fyrirtaeki_fjoldi_launagreidendur/ FYR01203.px/

Hagstofa Íslands (2017b). Gisting. Sótt 5. febrúar 2017 af https://hagstofa.is/talnaefni/atvinnuvegir/ferdathjonusta/gisting/

Hagstofa Íslands (2017c). Sveitarfélög og byggðakjarnar. Sótt 29. janúar 2017 af https://www. hagstofa.is/talnaefni/ibuar/mannfjoldi/sveitarfelog-og-byggdakjarnar/

Hagstofa Íslands (2017d). Vöru- og pjónustuviðskipti. Sótt 29. janúar 2017 af https://hagstofa. is/talnaefni/efnahagur/utanrikisverslun/voru-og-thjonustuvidskipti/

Hall, C. M. og Frost, W. (ritstj.) (2009). Tourism and national parks: International perspectives on development, histories and change. London: Routledge.

Hjalti Jóhannesson, Enok Jóhannsson, Jón Porvaldur Heiðarsson, Kjartan Ólafsson, Sigrún Sif Jóelsdóttir og Valtýr Sigurbjarnarson (2010). Rannsókn á samfélagsáhrifum álvers- og virkjunarframkvæmda á Austurlandi. Lokaskýrsla: Stöðulýsing í árslok 2008 og samantekt yfir helstu áhrif 2002-2008. Rannsóknarrit nr. 9. Akureyri: Byggðarannsóknastofnun Íslands.

Karl Benediktsson og Anna Karlsdóttir (2011). Iceland: Crisis and regional development: Thanks for all the fish? European Urban and Regional Studies, 18(2), 228-235. doi: $10.1177 / 0969776411402282$

Karl Benediktsson og Guðríður Porvarðardóttir (2005). Frozen opportunities? Local communities and the establishment of Vatnajökull national park, Iceland. Í D. B. A. Thompson, M. F. Price og C. A. Galbraith (ritstj.), Mountains of Northern Europe: Conservation, management, people and nature. Edinborg: Scottish Natural Heritage.

Karl Benediktsson og Unnur Dís Skaptadóttir (2002). Coping strategies and regional policies - Social capital in the Nordic peripheries - Country report Iceland. Stokkhólmi: Nordregio.

Kitchin, R. og Tate, N. J. (2000). Conducting research in human geography: Theory, methodology and practice. Harlow: Pearson Education. 
Krippendorf, J. (1982). Towards new tourism policies: The importance of environmental and sociocultural factors. Tourism Management, 3(3), 135-148. doi: 10.1016/02615177(82)90063-2

Magnfríður Júlíusdóttir, Anna Karlsdóttir, Karl Benediktsson, Inga Elísabet Vésteinsdóttir og Sigfús Steingrímsson (2009). Litróf búskapar og byggða. Reykjavík: Land- og ferðamálafræðistofa, Líf- og umhverfisvísindadeild.

Orkustofnun (2015). Raforkuspá 2015-2050. Reykjavík: Orkustofnun.

Orkustofnun. (2016). Orkutölur 2015. Reykjavík: Orkustofnun.

Porter, M. E. (1980). Competitive strategy: Techniques for analyzing industry and competitors. New York: Free Press.

Porter, M. E. (1990). The competitive advantage of nations. New York: Free Press.

Priestley, T. og Evans, G. W. (1996). Resident perceptions of a nearby electric transmission line. Journal of Environmental Psychology, 16, 65-74. doi: 10.1006/jevp.1996.0006

Rannveig Ólafsdóttir og Micael Runnström (2010). Endalaus víðátta? Mat og kortlagning íslenskra víðerna. Náttúrufræðingurinn, 81(2), 57-64.

Ritchie, J. R. B. og Crouch, G. I. (2003) . The competitive destination: A sustainable tourism perspective. Oxon: Cabi Publishing.

Sharpley, R. og Vass, A. (2006). Tourism, farming and diversification: An attitudinal study. Tourism Management, 27, 1040-1052. doi: 10.1016/j.tourman.2005.10.025

Stefán Gíslason (ritstj.) (2016). Verkefnisstjórn 3. áfanga verndar- og orkunýtingaráxtlunar: Drög að lokaskýrslu. Reykjavík: Verkefnisstjórn 3. áfanga verndar- og orkunýtingaráætlunar 2013-2017.

Talbot, C. (1998). The wilderness narrative and the cultural logic of capitalism. Í J. B. Callicott og M. P. Nelson (ritstj.), The Great New Wilderness Debate (bls. 325-326). Athens: The University of Georgia Press.

U.S. Energy Information Administration (2016). International Energy Statistics: Total Renewable Electricity Net Generation 2015. Sótt 26. janúar 2017 af http://www.eia.gov/beta/international/rankings/\#?cy=2015\&aid=12\&pid=29\&tl_id=2-A\&ug=8

Umhverfisstofnun. (2009). Ósnortin víðerni. Reykjavík: Umhverfisstofnun.

Unnur Birna Karlsdóttir. (2010). Náttúrusýn og nýting fallvatna: Um viðhorf til náttúru og vatnsaflsvirkjana á Íslandi 1900-2008. Reykjavík: Hugvísindastofnun.

Unnur Birna Karlsdóttir (2013). Nature worth seeing! The tourist gaze as a factor in shaping views on nature in Iceland. Tourist Studies, 13(2), 139-155. doi: 10.1177/1468797613490372

Viðskiptaráð Íslands (2011). Tökumst á við tækifærin: Atvinnulíf til athafna. Reykjavík: Viðskiptaráð Íslands.

Vífill Karlsson (2017). Fjöldi ferðamanna og tekjur og kostnaður íslenskra sveitarfélaga (grein í vinnslu). Stjórnmál og stjórnsýsla.

Pingskjal nr. 934/1989-1990: Tillaga til pingsályktunar um ferðamálastefnu.

Póroddur Bjarnason (2012). Hagsmunir íslenskra sjávarbyggða við endurskoðun fiskveiðistjórnunar. Tímarit um viðskipti og efnahagsmál, 9(2). 
